\title{
Kur'ân'ın İstinsah Heyetinde Bulunan Saîd b. el-Âs Kimdir?
}

Who is Saîd b. al-As in the commission for the reproduction of the Holy Quran?

\section{Doç. Dr. Hasan YERKAZAN}

Amasya Üniversitesi, İlahiyat Fakültesi, Temel İslam Bilimleri Anabilim Dalı

Assoc. Prof., Amasya Uni., Faculty of Divinity, Department of Basic Islamic Sciences, Amasya, Turkey. hasanyerkazan@gmail.com

(iD 0000-0001-8673-0546

\begin{tabular}{lcc}
\multicolumn{2}{c}{$\begin{array}{c}\text { Makale Bilgisi / Article Information } \\
\text { Makale Türü / Article Type }\end{array}$} & Araştırma Makalesi / Research Article \\
Geliş Tarihi / Received & Kabul Tarihi / Accepted & Yayın Tarihi / Published \\
15 Mayıs / May 2021 & 16 Ağustos / August 2021 & 23 Eylül / September 2021
\end{tabular}

Atıf Bilgisi / Cite as:

Yerkazan, Hasan. “Kur'ân'ın İstinsah Heyetinde Bulunan Saîd b. el-Âs Kimdir?”, Eskişehir Osmangazi Üniversitesi İlahiyat Fakültesi Dergisi 8/2 (Eylül 2021), 38-65.

http://doi.org/1051702/esoguifd.937452

Intihal / Plagiarism: Bu makale, en az iki hakem tarafından incelenmiş ve intihal içermediği teyit edilmiştir. / This article has been reviewed by least two referees and scanned via a plagiarism software.

Copyright @ Published by Eskişehir Osmangazi Üniversitesi, İlahiyat Fakültesi /Eskişehir Osmangazi University, Faculty of Theology Bütün hakları saklıdır. / All right reserved. https://dergipark.org.tr/tr/pub/esoguifd

CC BY-NC 4.0 This paper is licensed under a Creative Commons Attribution-NonCommercial License

Etik Beyanı / Ethical Statement: Bu çalışmanın hazırlanma sürecinde bilimsel ve etik ilkelere uyulduğu, yararlanılan tüm çalışmaların kaynakçada belirtildiği ve bu araştırmanın desteklenmesi için herhangi bir dış fon almadıkları yazar tarafından beyan olunur / It is declared by the author that scientific and ethical principles have been followed while carrying out and writing this study; that all the sources used have been properly cited; that no external funding was received in support of the research. 


\section{Kur'ân'ın İstinsah Heyetinde Bulunan Saîd b. el-Âs Kimdir?}

Öz \u makalede İslâm tarihinde müstesna bir yere sahip olan Saîd b. el-Âs (öl. 58/678) farkl boyutlarıyla incelenmeye çalışılmıştır. O, hicret yılında Mekke'de dünyaya gelmiştir. Babası Bedir savaşında müşriklerin safında öldürüldükten sonra Hz. Osman (öl. 35/656) onu himayesi altına almıştır. Cesaret, dirâyet, hitâbet, fesâhat, cömertlik gibi bazı özelliklerinden dolayı insanlar arasında temayüz etmiş ve genç yaşta stratejik öneme sahip görevler üstlenmiştir. Ermenistan ve Azerbaycan seferlerinde komutan olarak orduyu yönetmiş ve önemli başarılar elde etmiştir. Askerî görevlerinin yanı sıra Hz. Osman döneminde Kûfe'de; Muâviye (öl. 60/680) döneminde ise Medine'de valilik yapmıştır. Kargaşanın hiç eksik olmadığı Kûfe'de valilik yaptığı dönemde yaşamış olduğu sıkıntılar azledilmesine sebep olmuştur. Hz. Osman'ın şehit edilmesi sürecinde onu korumaya çalışmış; Cemel ve Sıffın savaşlarında tarafsız kalmayı tercih etmiştir. Medine'de valilik yaptığı dönemde başta Ehl-i beyt olmak üzere her kesimle iyi ilişkiler içerisinde olmaya gayret etmiştir. Görev yaptığı yerlerde insanların ihtiyaçlarını karşılamış, özellikle yardıma muhtaç olan kimselere vermiş olduğu büyük miktardaki meblağlarla dikkat çekmiştir. O, Hz. Osman döneminde teşekkül ettirilen Kur'ân-1 Kerîm'in istinsah heyetinde bulunmuş, nüsha çoğaltılma sürecinde önemli bir sorumluluk üstlenmiştir.

Anahtar Kelimeler: İslâm Tarihi, Kur'ân Tarihi, Saîd b. el-Âs, Kûfe, Medine.

\section{Who is Saîd $b$. al-As in the commission for the reproduction of the Holy Quran?}

Abstract In this article, Saîd b. al-As (d. 58/678) has been tried to be studied with different dimensions. He was born in Mecca in the year of the Migration (Hicra). Othman (d. 35/656) took him under his protection after his father was killed by the polytheists in the Battle of Badr. His courage, acumen, eloquence, language skills, generosity etc. He stood out among people due to some of his features such as and took on strategically important roles at a young age. He led the army as a commander in Armenia and Azerbaijan campaigns and achieved significant successes. In addition to his military duties, in Kufa during the Othman period; During the Muawiyah (d. 60/680) period, he was the governor of Medina. He tried to protect Osman during the process of martyrdom; he preferred to remain neutral in the wars of Cemel and Siffin. During the period when he was governor in Medina, he tried to be in good relations with all segments, especially Ahl al-Bayt. He met the needs of the people in the places he worked, and he attracted attention especially with the large amounts he gave to the people in need. He was in the committee of the Quran that was formed during the period of Othman and took an important responsibility in the process of reproducing the copies.

Keywords: Islamic History, Quran History, Said b. al-As, Kufa, Medina.

\section{Giriş}

İnsanlık tarihinin en önemli hâdiselerinden biri hiç şüphesiz Hz. Muhammed'in (s.a.s.) Allah tarafından peygamber olarak gönderilmesidir. Ona kitap olarak Kur'ân-1 Kerîm inzâl olmuştur ve onun en büyük mucizesidir. Kur'ân, Rasûlullah'a vahyedilmeye başladığı ilk günden itibaren her bir âyeti titiz bir şekilde sadırlarda ve satırlarda muhafaza edilmiştir. Resûl-i Ekrem'in vefatından 
sonra ihtiyaca binaen Hz. Ebû Bekir (öl. 13/634) döneminde Zeyd b. Sâbit'in (öl. 45/665) öncülüğünde oluşturulan bir komisyon marifetiyle âyetlerin yazılı olduğu malzemeler bir araya getirilerek Mushaf teşekkül ettirilmiştir. Hz. Osman döneminde gelindiğinde ise başka bir zaruretten dolayı Mushaf bir komisyon eliyle istinsah edilmiş ve İslâm coğrafyasının muhtelif beldelerine gönderilmiştir. ${ }^{1}$

İslâm dinin en temel kaynağı olan Kur'ân-1 Kerîm'in tarihî süreç içerisinde geçirmiş olduğu tüm safhalar yani âyetlerin nâzil olmasından cemedilmesine, istinsahından tefsirlerinin yapılmasına kadar başta Kur'ân tarihi olmak üzere İslâmî ilimlerin bütün alanları açısından büyük önemi haizdir. Bugüne kadar Kur'ân-1 Kerîm ile ilgili birçok konu belli başlı çalışmalara konu olmuştur. Bu makalede ise Kur'ân'ın istinsahı yani çoğaltılması sürecinde aktif rol alan Saîd b. elÂs (öl. 58/678) farklı yönleri ile tetkik edilecek ve değerlendirilecektir. İslâm ve Kur'ân tarihi açısından oldukça değerli bir sürecin içerisinde görev almış olması onun daha yakından tanınmasını gerekli kılmaktadır. Tespit edilebildiği kadarıyla Saîd b. el-Âs, bugüne kadar makale, kitap ve tez düzeyinde herhangi bir akademik çalışmaya konu olmamıştır. Bu çalışmanın asıl amacı, Kur'ân tarihi ile ilgili yapılacak kapsamlı çalışmalara mütevazı bir katkıda bulunmaktır. Her ne kadar Saîd b. el-Âs'ın Kur'ân'ın istinsah heyetinde bulunma süreci bu çalışmanın ana konusunu oluştursa da doğumundan ailesine, valiliklerinden hadîs rivâyetlerine kadar birçok yönü farklı boyutlarıyla imkanlar ölçüsünde burada ele alınmaya çalışılacaktır.

Saîd b. el-Âs kimdir? Siyâsî ve askerî olarak hangi görevlerde bulunmuştur? Mushafin istinsah heyetine neden seçilmiştir ve buradaki görevi nedir? Kûfe ve Medine valilikleri döneminde ne tür hâdiseler ile karşılaşmıştır? Hz. Osman'ın şehit edilmesi sürecinde neler yaşamıştır? Cemel ve Sıffın savaşında hangi tarafta bulunmuştur? Dikkat çeken ahlâkî özellikleri nelerdir? Kaç tane hadîs rivâyet etmiştir? gibi soruların cevapları makale sınırları içerisinde aranmaya çalışılacaktır.

\section{Ailesi ve Çocukluk Dönemi}

Tam adı Saîd b. el-Âs b. Sâid b. el-Âs b. Ümeyye b. Abdüşşems b. Abdumenaf el-Kureşî elUmevî'dir. Hicret yılında Mekke'de dünyaya gelmiştir. Babası el-Âs, Bedir savaşında müşriklerin safında yer almış olup Hz. Ali (öl. 40/661) tarafından öldürülmüştür. Kureyş kabilesinin ileri gelenlerinden biri olan dedesi Ebû Ecniha Saîd b. el-Âs da müşrik olarak vefat etmiştir. Çocuk yaşta yetim kalan Saîd, kendisi ile aynı aileye mensup olan Hz. Osman'ın himayesinde büyümüştür. Hz. Osman şehit oluncaya kadar onun en yakınlarından biri olmuştur. O, dokuz yaşında iken Rasûlullah (s.a.s.) vefat etmiştir. Hz. Peygamber'i görmesi sebebiyle sahabî kabul edilmiştir. ${ }^{2}$ Hayatı

1 Bk. Mehmet Emin Maşalı, "Mushaf”, Türkiye Diyanet Vakfı İslam Ansiklopedisi (İstanbul: TDV Yayınları, 2006), 31/242-243.

2 Ebû Ömer Cemâlüddîn Yûsuf b. Abdillâh b. Muhammed İbn Abdilberr en-Nemerî, el-İstî‘̂ab fi ma'rifeti'l-ashâb, thk. Ali Muhammed el-Becâvî (Beyrut: Dâru'l-Cîl, 1992), 2/622; Ebü'l-Fazl Cemâlüddîn Muhammed b. Mükerrem 
boyunca önemli vazifelerde bulunmuş ve halk tarafından büyük bir teveccüh görmüştür. Muhtemelen ilk ve en önemli ilgiyi Hz. Peygamber'den görmüştür. İbn Ömer'den (öl. 73/695) nakledildiğine göre, kadının biri, Rasûlullah'a bir hırka getirmiş ve şöyle demiştir: "Ey Allah'ın Rasûlü! Ben bu hırkayı Arapların en şereflisine vermeyi adadım." Rasûlullah da orada bulunan Saîd'i işaret ederek demiş ki: "Öyle ise şu gence bunu ver." Bu hâdise, henüz çocuk yaşta Saîd'in Arapların en şereflisi olarak taltif edilmesine sebep olmuştur. Hz. Peygamber'in istikbalde yapacağ 1 hizmetlerden dolayı onu böyle bir payeye layık görmesi ihtimal dahilindedir. Ayrıca bu rivâyet, Rasûlullah'ın Sâid'i sevdiğini ve ona değer verdiğini de göstermektedir. Bu olay dişında onun çocukluk ve gençlik dönemine dair herhangi bir malumat tespit edilememiştir. Kaynaklarda Saîd b. el-Âs ile ilgili ayrıntılı bilgiler, daha çok onun yetişkinlik dönemine aittir. İlk olarak Ermenistan ve Azerbaycan seferlerinde üstlendiği görevlerle İslâm tarihinde yer almıştır.

\section{Ermenistan ve Azerbaycan Seferleri}

Hz. Ömer'in (öl. 23/644) emriyle Sa'd b. Ebî Vakkas (öl. 55/675) tarafından 17/638 tarihinde Güney Irak'ta Fırat'ın batı kolu üzerinde kurulan Kûfe, doğuya yapılan seferlerin merkezi haline gelmiştir. Hz. Ömer'in vasiyeti gereği Hz. Osman halife seçildikten sonra Muğire b. Şu'be'yi (öl. 50/670) görevden almış, Sa'd b. Ebî Vakkas'ı yeniden Kûfe valisi olarak atamıştır. Sa'd yaklaşık bir buçuk yıl burada görev yaptıktan sonra 26/647 tarihinde azledilmiş yerine Osman'ın anne bir kardeşi Velid b. Ukbe b. Ebî Muayt (öl. 61/681) tayin edilmiştir. Velid, Kûfe'ye tayin edildikten sonraki günlerde Azerbaycan ve civarındaki halk, Hz. Ömer zamanında yapılmış olan anlaşmayı bozarak isyan etmiştir. İsyanı bastırmak ve bu bölgeyi fethetmek üzere Saîd b. el-Âs ordu komutanı olarak görevlendirilmiş ve burada büyük bir başarı elde etmiştir. Saîd'in bu fetih hareketlerinde göstermiş olduğu başarısı, onun bundan sonraki dönemde daha da görünür olmasına imkân sunmuştur. Bu fetih esnasında askerler arasında Kur'ân'ın okunuşu ile ilgili yaşanan bir hâdise, onun Kur'ân tarihi açısından oldukça önemli olan bir görev üstlenmesine sebep olmuştur.

b. Alî b. Ahmed İbn Manzûr el-Ensârî er-Rüveyfî̂, Muhtasaru Târîhi Dımaşk (Dımaşk: Dâru'l-Fikr, 1984), 9/306; Ebü'l-Fidâ' İmâdüddîn İsmâîl b. Şihâbiddîn Ömer İbn Kesîr ed-Dımaşkī, el-Bidâye ve'n-nihâye (Dımaşk: Dâru'l-Fikr, 1986), 8/83; Şemsüddîn Muhammed b. Ahmed b. Osman ez-Zehebî, Siyeru aqami'n-nübela, thk. Şuayb Arnaûd (Beyrut: Müessestü'r-Risale, 1982), 3/445; Ebü'l-Fazl Şihâbüddîn Ahmed b. Alî b. Muhammed İbn Hacer elAskalânî, el-İsâbe fî temyîzi'ș-ṣahâbe, thk. Âdil Ahmed Abdülmevcûd, Ali Muhammed Muavvid (Beyrut: Dâru'lKütübi'l-i̇lmiyye, 1994), 2/90; Ebü'l-Haccâc Cemâlüddîn Yûsuf b. Abdirrahmân b. Yûsuf el-Mizzî, Tehzîbü'l-Kemâl fî esmâ'i'r-ricâl, thk. Beşşâr Avvâd Ma'ruf (Beyrut: Müessesetü'r-Risâle, 1980), 10/502.

3 İbn Manzûr, Muhtasaru Târîhi Dımașk, 9/306; Mizzî, Tehzîbü'l-Kemâl fî esmâ'i’r-ricâl, 10/504; İbn Kesîr, el-Bidâye ve'n-nihâye, 8/84.

4 Adem Apak, “Hz. Osman Dönemi Fetihleri”, Uludağ Üniversitesi İlahiyat Fakültesi Dergisi 9/1 (01 Ocak 2000), 437438.; Adnan Adigüzel, “Hz. Osman Döneminde (24-35/644-656) Fetihler”, Şarkiyat 11/3 (31 Aralık 2019), 11801182. 
Yerkazan, Kur'ân İstinsah Heyetinde Bulunan Saîd b. el-Âs kimdir?

\section{Mushafin İstinsahı Heyetinde Bulunmas1}

Azerbaycan ve Ermenistan fetihleri sırasında Hz. Peygamber'in sırdaşı Huzeyfe b. Yemân (öl. 36/656) Iraklı ve Suriyeli askerler arasında Kur'ân'ın farklı kıraatlerle okunduğunu görünce dehşete kapılmış ve sefer dönüşünde Hz. Osman'ın huzuruna çıarak “Ey Mü’minlerin emiri! Yahûdî ve Hristiyanların ihtilafı gibi, bu ümmet Kur'ân'da bir ihtilafa düşmeden, acele tedbir al" diyerek bu karışıklığa son vermesi için onu uyarmış ve insanların tek bir kıraat etrafında toplanması gerektiğini bildirmiştir. ${ }^{5}$

$\mathrm{Bu}$ önemli ve tarihi uyarıyı dikkate alan Hz. Osman, Hz. Hafsa'nın (öl. 45/665) yanında bulunan Mushaf' 1 istetmiş ve bir heyet oluşturarak Kur'ân'ın istinsahı sürecini başlatmıştır. Rivâyet edildiğine göre, Kureyş ve ensârdan on iki kişi bu süreçte görevlendirilmiştir. Übey b. Ka‘b (öl. 33/654), Abdurrahmân b. Hâris b. Hişâm (öl. 43/663-4), Zeyd b. Sâbit, Saîd b. el-Âs ve Abdullah b. Zübeyr (öl. 73/692) gibi kişiler bu heyette önemli görevler üstlenmişlerdir. ${ }^{6}$

Saîd b. el-Âs'ın Azerbaycan ve Ermenistan fetihleri esnasında farklı Kur'ân okunuşlarına bizzat ordu komutanı olarak şahit olmasının, bu heyet içerisinde yer almasındaki en etkili âmil olabileceği akla gelmektedir. Tabii bu ihtimal dahilindedir. Ancak onun bu komisyonda bulunmasının asıl sebebi Kur'ân bilgisi, Arap diline hakimiyeti, beliğ ve fasih dil becerisine sahip oluşudur. Ayrıca lehçe bakımından Hz. Peygamber'e benzerliği de onun istinsah heyetinde görevlendirilmesinde etkili olmuştur.?

Komisyonda bulunan kişilerin seçiminde liyakat esas alınmıştır. ${ }^{8}$ Hz. Osman, Kur'ân'ın herhangi bir kelimesinde bir ihtilafa düşülmesi halinde Kureyş lehçesini esas almalarını istemiştir. Kur'ân nüshalarının çoğaltılması sürecinde Übey b. Ka'b imla ettirmiş, Zeyd b. Sâbit yazmış ve Saîd b. el-Âs ise irabını kontrol etmiştir. ${ }^{9}$ Bazen kelimelerin yazımında ihtilaflar olmuştur. Mesela, elBakara sûresinin 248. âyetinde geçen "التابوت "kelimesinin yazımı ile ilgili bir sorun yaşanmıştır.

5 Ebû Muhammed Abdullâh b. Vehb el-Misrî el-Kureşî İbn Vehb, Tefsîru'l-Kur'ân, thk. Miklos Muranyi (Beyrut: Dâru'l-Ğarbi'l-İslâmî, 2003), 3/26.; Ebû Abdillâh Muhammed b. İsmail el-Buhârî, el-Câmi'u's-sahîh, thk. Muhammed Züheyr b. Nasr (b.y.: Dâru Tavki'n-Necât, 1422/2001), "Fedâilu'l-Kur'ân", 3.

6 İbn Manzûr, Muhtasaru Târîhi Dimaşk, 9/310.

7 Ebû Bekr Abdullah b. Ebî Dâvûd Süleymân b. Eş'as es-Sicistânî, Kitâbu'l-mesâhif, thk. Muhammed b. Abduh (Kahire: el-Faruku'l-Ḥadīse, 2011), 102; Ebü'l-Kāsım Müsnidü'd-dünyâ Süleymân b. Ahmed b. Eyyûb et-Taberânî, el-Mu'cemu'l-kebîr, thk. Hamdi Abdulmecîd es-Selefî (Kahire: Mektebetü İbn Teymiyye, 1983), 6/60; İbn Abdilberr, el-İstî́âb fî ma 'rifeti'l-așhâab, 2/622; Mizzî, Tehżîü'l-Kemâl fî esmẩi’r-ricâl, 10/502; Zehebî, Siyeru a lami'nnübela, 3/447; İbn Kesîr, el-Bidâye ve'n-nihâye, 8/84; İbn Hacer, el-İșâbe fî temyîzi'ṣ-șahâbe, 2/90;

8 Davut Ağbal, Tertîbu'l-Kur'ân (Ankara: Sonçağ Akademi), 66.

9 İbn Ebî Dâvûd, Kitābu'l-mesâhif, 100.; Ebû Şâme Abdurrahman b. İsmail el-Makdisî, el-Murşidu'l-vecîz 'ilâ 'ulûmin tete'allku bi'l-kitâbi'l-'azîz, thk. Tayyar Altıkulaç (Beyrut: Dâru Sadır, 1975), 65; Ebû Zeyd Ömer b. Şebbe enNümeyrî el-Basrî, Târîhu'l-Medîne, thk. Fehim Muhammed Şeltût (Cidde: y.y., 1979), 3/1136. 
Zeyd bu kelimenin “التابوة" șeklinde yazılması gerektiği söylemiştir. Saîd b. el-Âs ve İbn Zübeyr ise "التابوت olarak yazılması hususunda görüş beyan etmişler ve bu durum Hz. Osman'a intikal ettirilmiştir. Hz. Osman, kelimenin Kureyş lehçesine uygun olarak Saîd'in dediği şekliyle " "التابوت " olarak yazılmasını bildirmiştir. Kur'ân'ın çoğaltılma süreci sona erdikten sonra ${ }^{10} \mathrm{~Hz}$. Hafsa'dan alınan asıl Mushaf tekrar ona iade edilmiştir. ${ }^{11}$

Mushafın çoğaltılması sürecinde yukarıda belirtilen örnek dışında kaynaklarda detaylı bilgiler tespit edilememiştir. Yani bu süreçte başka ihtilaflar oldu mu? Komisyon günde ne kadar çalıştı? Nüshalar kaç gün veya kaç ayda tamamlandı? şeklindeki soruların tam olarak cevapları tespit edilememiştir. Ancak tarihî olaylardan bazı çıkarımlarda bulunmak mümkündür. Mushafın istinsahı meselesi daha önce de izah edildiği üzere Azerbaycan ve Ermenistan seferleri sonrasında gündeme gelmiştir. Bu savaş Velid b. Ukbe b. Ebî Muayt'ın 26/647 tarihinde Kûfe'ye vali olarak tayin edildiği günlerde gerçekleşmiştir. Dolayısıyla bu tarihten sonraki bir zaman diliminde Kur'ân'ın istinsah sürecinin başladığı söylenebilir. Peki bu faaliyet kaç yıl sürmüştür? O da yine Velid b. Ukbe'nin Kûfe valiliğinden 30/650 tarihinde azledilmesi ile ilişkilendirmek mümkün olabilir. Zira istinsah heyetinde bulunan Saîd b. el-Âs, Velid'ten sonra Kûfe'ye vali tayin edilmiştir. $\mathrm{Bu}$ bilgiden hareketle Mushaf nüshalarının 26/647-30/650 tarihleri arasında çoğaltıldığını ifade etmek mümkündür. Ayrıca Hz. Osman'ın hilafete geçtiği tarih 23/644 göz önünde bulundurulduğunda, onun göreve geldiği tarihten üç yıl sonra bu sürecin yaşandığı söylenebilir.

Saîd b. el-Âs'ın bu süreçte bir yandan ordunun komutanı diğer yandan Kur'ân'ın istinsahı gibi oldukça önemli ve hassas bir vazife içinde bulunduğu müşahede edilmektedir. Kûfe valiliği de onun üstlenmiş olduğu önemli vazifelerden biridir.

\section{Kûfe Valiliği}

Hz. Osman'in terbiyesi altında yetişen Saîd, çok genç yaşta bilgisi ve tecrübesiyle kendini ispat etmiştir. Velid b. Ukbe b. Ebî Muayt'in azlinden sonra Hz. Osman 30/650 tarihinde onu Kûfe valisi olarak tayin etmiştir. ${ }^{12}$ Hicret onun doğum tarihi kabul edildiğinde Saîd bir el-Âs'ın bu dönemde 30 yaşında olduğunu söylemek mümkündür.

10 İbn Şebbe, Târîhu'l-Medîne, 3/995, 1002; Ebû Îsâ Muhammed b. Îsâ et-Tirmizî, Sünenü't-Tirmizî, thk. Beşşâr Avvâd Ma'ruf (Beyrut: Dâru'l-Garbi'l-İslâmî, 1998), "Tefsîru'l-Kur'ân", 11; Ebû Bekir Ahmed b. el-Hüseyin el-Beyhakî, es-Sünenü'l-kübra, thk. Muhammed Abdulkadir Atâ (Beyrut: Dâru'l-Kütübi'l-İlmiyye, 2003), 2/538.;

11 Ebû Ubeyd Kāāım b. Sellâm el-Herevî, Fedẩilu'l-Kur'ân, thk. Mervân el-Atiyye, Muhsin Hirâbe, Vefâ Takiyuddîn (Beyrut - Dimaşk: Dâru İbn Kesîr, 1995), 282.; Buhârî, "Fedâilu'l-Kur'ân", 3; Tirmizî, "Tefsîru'l-Kur’ân", 10; İbn Şebbe, Târîhu'l-Medîne, 3/991.

12 Apak, "Hz. Osman Dönemi Fetihleri”, 437-446.; Adigüzel, “Hz. Osman Döneminde (24-35/644-656) Fetihler”, 1180-1181. 
Saîd b. el-Âs, Kûfe bölgesinde yaşanan bir olaydan sonra bölgedeki huzur ve sükunu sağlamak amaciyla Hz. Osman döneminde buraya gönderilmiştir. ${ }^{13}$ Hâdise şöyle gerçeklemiştir: Kûfe valisi Sa'd b. Ebî Vakkâs ile vergi toplama görevlisi Abdullah b. Mes'ûd arasında ödünç bir malın zamanında teslim edilmemesinden dolayı bir tatsızlık yaşanmıştır. Huzursuzluk büyüyünce durum Hz. Osman'a intikal ettirilmiştir. Hz. Osman, sükûnu sağlamak için Sa'd'ı azledip yerine Hz. Ömer döneminde Arap yarımadasının batı bölgesinde vergi memuru olarak istihdam edilen Velid $b$. Ukbe'yi Kûfe'ye vali tayin etmiştir. Velid kısa zaman içerisinde huzuru sağlamış ve halk tarafından da sevilmiştir. Ancak Kûfe'de yaşanan bir cinayet neticesinde suçluların kısas yapılıp öldürülmesi, birtakım sorunların ortaya çıkmasına sebep olmuştur. Velid b. Ukbe'ye kin güden suçluların aileleri, onu içki meclislerinde bulunduğu söyleyerek dedikodusunu yapmak suretiyle yıpratmaya çalışmışlardır. Bu hâdise Hz. Osman'a intikal ettirildikten sonra Velid görevden alınmış ve Saîd b. el-Âs tayin edilmiştir. O, Kûfe'ye geldiğinde kısa zaman içerisinde kargaşanın ve fitnenin kaynağını tespit etmiş, halkı uyararak gerekli tedbirleri almaya çalışmıştır. ${ }^{14}$

Saîd b. el-Âs, Kûfe'ye geldiğinde kendisini bir kargaşa ve kaosun içinde bulmuştur. Her ne kadar Kûfe'ye vali olarak geldiğinde genç ve tercübesiz bir kişi olsa da kısa zaman içerisinde kendisini halka kabul ettirmeye çalışmıştır. Kûfe'nin ileri gelenlerinin, bilginlerinin, kurrâlarının ve âlimlerinin katıldığı bir meclis teşekkül ettirmiştir. Halkla içli dışlı olmuştur. ${ }^{15}$ Ancak onun uygulamalarına bakıldığında sert bir yönetim tarzı benimsediği anlaşılmaktadır. Daha sonra da izah edileceği üzere Hz. Ömer'in üslûbunu kendisine rehber aldığını söylemek mümkündür. Bu tavrından dolayı daha sonraki süreçte Kûfeliler onu "eşgar bereke" (göğsü kıllı) olarak lakaplandırmışlardır. Bu lakap onun güçlü, gözü pek ve dirayetli olduğunu göstermektedir. ${ }^{16}$ Şairler onun hakkında şöyle demişlerdir: ${ }^{17}$

$$
\text { يا ويلتا قد ذهب الوليد ... وجاءنا من بعده سعيد }
$$

"Eyvah! Velid gitti, ondan sonra bize Saîd geldi."

Saîd b. el-Âs, Kûfe'ye vali tayin edildiği günlerde Azerbaycanlılar, Müslümanlar ile yapmış oldukları antlaşmayı bozmuşlardır. Saîd, onların üzerlerine gitmiş Taberistan ve Cürcan'ı

13 Zehebî, Siyeru aclami'n-nübela, 3/445.

14 İbn Manzûr, Muhtasaru Târîhi Dımaşk, 9/306; İbn Kesîr, el-Bidâye ve’n-nihâye, 8/84; Zehebî, Siyeru a lami’n-nübela, 3/445; Hakkı Dursun Yıldız, Doğuştan Günümüze Büyük İslam Tarihi (İstanbul: Çağ Yayınları, 1992), 2/202-205.

15 İbn Manzûr, Muhtasaru Târîhi Dımaşk, 9/306; İbn Kesîr, el-Bidâye ve’n-nihâye, 8/84; Zehebî, Siyeru a'lami'n-nübela, 3/445; Yıldız, Doğuştan Günümüze Büyük İslam Tarihi, 2/202-205.

16 Ebü'l-Velîd Muhammed b. Abdillâh b. Ahmed b. Muhammed el-Ezrakī, Ahbâru Mekke, thk. Rüşdî Sâlih Melhas (Beyrut: Dâru'l-Endülüs, 1979), 2/236.

17 İbn Abdilberr, el-İstî‘̂ab fî ma'rifeti'l-ashâb, 2/622. 
fethetmiştir. ${ }^{18} \mathrm{Bu}$ sefer esnasında askerleri arasında Huzeyfe b. el-Yemân da bulunmuştur. Taberistan'da savaşın kızıştığı bir anda Saîd, Rasûlullah (s.a.s.) ile beraber hanginiz korku namazı kıldı?" diye sormuştur. Huzeyfe, bu namazı Hz. Peygamber ile kıldığını belirtmiştir. Salât-ı havfın yani korku namazının nasıl kıldırıldığını orada Huzeyfe tarif etmiş ve bu şekilde namazlar eda edilmiştir. Saîd, Rasûlullah vefat ettiğinde henüz çocuk yaşta olduğundan dolayı bazı hâdiselere şahit olmamıştır. Ancak oü bu rivâyetten de anlaşılacağı üzere ihtiyaç olması halinde dinî konularda tecrübeli kişilerin görüşlerine müracaat etmiştir. Bu bağlamda korku namazı ile ilgili çok sayıda rivâyet bu hâdise ile bağlantılı olarak nakledilmiş ve hadîs kaynaklarında yer almıştır. ${ }^{19}$

Saîd b. el-Âs görev yaptığı süre zarfinda diğer valiler ile birlikte Medine'ye gelerek Hz. Osman'a bulundukları bölgelerde yaşananlar ile ilgili bilgiler vermiştir. ${ }^{20}$ Saîd, Medine halkına hediyeler göndermiş ve Hz. Ali'yi bu hususta kayırmıştır. Elçisine "Kardeşinin oğlu sana selam söylüyor. Sana gönderdiğim kadar başka bir kimseye hediye göndermedim. Ki o kadar hediye ancak Emirü'l-mü'mininin hazinesinde olur" demesini istemiştir. Hz. Ali cevap olarak "Beni en çok düşündüren Muhammed'in (s.a.s.) mirasıdır. Vallahi, ona bir sahip olursam, toprağa düşen ciğer parçasını silkeleyip temizler gibi onu temizleyeceğim" demiştir. ${ }^{21} \mathrm{~Hz}$. Ali bu sözleriyle sanki bu işten çok memnun olmadığını Hz. Peygamber'in mirasının çarçur edildiğini söylemiştir. Kaynaklarda yeterli bilgi tespit edilemediğinden dolayı bu diyalogun mahiyetini tam olarak anlayıp ve yorumlamak oldukça güç görünmektedir. Ancak Saîd b. el-Âs'ın Hz. Ali ile iyi bir diyalog içerisinde olmak istediğini söylemek mümkündür. Daha sonra ele alınacağı üzere Hz. Osman'ın şehit edilmesinden sonraki süreçte takındığı tavır da bunu göstermektedir. Ayrıca bir hac mevsiminde Mekke'de hastalanan Saîd b. el-Âs'ı Hz. Ali'nin ziyaret etmiş olması, aralarında bir ünsiyetin olduğunu da söylemek mümkündür. ${ }^{22}$ Ya da babasını Bedir'de öldüren $\mathrm{Hz}$. Ali ile sorununun olmadığını bu tür davranışları ile göstermeye çalışmış olabilir.

18 İbn Abdilberr, el-İstî‘̂ab fî ma'rifeti'l-așhâb, 2/622; Mizzî, Tehzîbü'l-Kemâl fî esmâ’i'r-ricâl, 10/502; İbn Kesîr, el-Bidâye ve'n-nihâye, 8/84; Zehebî, Siyeru a'lami'n-nübela, 3/445; İbn Hacer, el-İsâbe fì temyîzi's-sahâbe, 2/90.

19 Bk. Ebû Bekr Abdullah b. Muhammed İbn Ebî Şeybe, el-Musannef, thk. Muhammed Avvâme (Beyrut: Dâru'l-Kıble, 2006), 2/461; Ahmed b. Hanbel, el-Müsned, thk. Şuayb Arnâût (Beyrut: Müessesetü'r-Risâle, 1999), 38/302; Ebû Dâvûd Süleymân b. el-Eş'as b. İshâk es-Sicistânî el-Ezdî, Sünenü Ebî Dâvûd, thk. Şuayb Arnâût, Muhammed Kâmil Karabellî (Beyrut: Dâru'r-Risâleti'l-'Âlemiyye, 2009), "Salatu's-sefer", 18.

20 Bk. İbn Şebbe, Târîhu'l-Medîne, 3/1097.

21 İbn Ebî Şeybe, el-Musannef, 21/118.

22 İbn Şebbe, Târîhu'l-Medîne, 3/1098. 
Rivâyet edildiğine göre, Saîd b. el-Âs'in Kûfe'den gönderdiği heyet, Hz. Osman'ı övünce orada bulunan Mikdâd (öl. 33/653) onların yüzüne toprak saçmış ve Rasûlullah "Sizi yüzünüze karşı öven meddahlarla karşılaşırsanız yüzlerine toprak saçın"23 rivâyetini bu vesile ile aktarmıştır.

Saîd b. el-Âs, Kûfe'de güçlü bir bağ oluşturmak için evlilik de yapmıştır. el-Ferâfisa isimli bir şahsın kızı ile evlenmiştir. Daha sonra bu bölge ile evlilik bağı kurmak isteyen Hz. Osman da Sâid'in baldızı Nâile ile nikahlanmıştır. ${ }^{24}$ Fitne ateşinin hiç sönmediği Kûfe'de Saîd b. el-Âs yaklaşık beş yıl görev yapmıştır. ${ }^{25}$ Yaşanan bazı hâdiseler onun süreç içerisinde azledilmesine sebep olmuştur. Şöyle ki:

Saîd b. el-Âs, Kûfe'de iken Ramazan ayının hilalini kim gördü? diye sormuş. Hâşim b. Utbe b. Ebî Vakkâs hilali gördügünü söylemiş. Ancak Saîd ona "Sen bu tek gözünle mi hilali gördün?” diye sorunca, Hâşim ona "Sen bu kadar insan arasında beni gözümden dolayı ayıplıyorsun, oysa ben gözümün birini Yermük Savaşı'nda kaybettim.” demiştir. Ertesi gün hilali gördüğünü söyleyen Hâşim, evinde orucunu bozmuş ve onun yanında bulunanlarda ona tabi olmuşlardır. Bu haber Saîd b. el-Âs'a ulaşınca insanlar arasında fitneye sebep olduğundan dolayı onu dövdürtmüş ve evini yaktırtmıştır. Bu olay üzerine Ümmü Hakem bnt. Utbe b. Ebî Vakkâs ve Nâfi b. Ebî Vakkâs Medine'ye gelmişler ve bu durumu Hz. Osman'a anlatarak şikayetçi olmuşlardır. Hz. Osman, Saîd b. el-Âs'ı haksız görmüş, onlara "O ve evi size aittir” demiştir. Yani bir şekilde kısas yapilabileceğini ifade etmiştir. Hz. Osman'ın bu sözü üzerine o günlerde henüz çocuk yaşta olan Ömer b. Sa'd b. Ebî Vakkâs, Saîd b. el-Âs'ın Medine'deki evine hızlı bir şekilde gitmiş ve orayı yakmıştır. Bu hâdise Hz. Aişe'ye (öl. 58/678) intikal edince, hemen Sa'd b. Ebî Vakkâs'a bir kişiyi göndermiş ve bu durumu sonlandırmasını talep etmiştir. $O$ da bunu yaparak hâdisenin daha fazla büyümesine engel olmuştur. ${ }^{26}$ Bu olay Kûfe'de başlayıp Medine'de devam eden bir kargaşanın çıkmasına sebep olmuştur. Huzursuzluğa asıl sebep olan ve Saîd b. el-Âs'ın Kûfe'de görevinden azledilmesi sürecini başlatan hâdise ise şöyle cereyan etmiştir:

Çeşitli konuların görüşüldüğü istişare ve müzakere meclisinde Saîd b. el-Âs, Sevâd-1 Irak'ın Kureyş'in bahçesi olduğu söylemiştir. Orada bulunan Mâlik el-Eşter en-Nehâ̂i’nin (öl. 37/657) baş1 çektiği bir grup, “Allah'ın bize kılıçlarımızla ihsan etmiş olduğu bu araziler nasıl Kureyş’in çiftliği oluyor?" diyerek itiraz etmiştir. Saîd b. el-Âs olaya hemen müdahale etmiş ve kargaşa çıaran grubun bu özel meclise girişini yasaklamıştır. Bu fitneci grup, Hz. Osman'ın emri ile önce Şam bölgesine gönderilmiş ve Humus bölgesine Abdurrahman b. Halid b. Velid'in (öl. 46/666) yanına

\footnotetext{
${ }^{23}$ Ahmed b. Hanbel, el-Müsned, thk. Şuayb Arnâût (Beyrut: Müessesetü’r-Risâle, 1999), 39/246; Taberânî, elMu'cemu'l-kebîr, 20/241.

24 Ebû Bekr Muhammed b. Ca'fer b. Muhammed es-Sâmerrî el-Harâitî, I'tilâlü'l-kulûb, thk. Hamdî ed-Demirdâş (Riyad: Mektebetü Nezâr Mustafa el-Bâz, 2000), 169.

25 Taberânî, el-Mu'cemu'l-kebîr, 20/367; Zehebî, Siyeru a'lami'n-nübela, 3/446.

${ }^{26}$ İbn Manzûr, Muhtasaru Târîhi Dımaşk, 9/307.
} 
sürülmüşlerdir. Burada iken yaptıklarından pişman olduklarını ifade etmişler, bu özürleri kabul edilmiş ve Kûfe'ye dönmelerine müsaade edilmiştir. ${ }^{27}$

Ancak fitne çıkarmaya alışkın olan bu grup rahat durmamıştır. Kargaşanın hiç eksik olmadığı Kûfe'de Mâlik el-Eşter öncülüğünde bir heyet, Medine'ye gelip Hz. Osman'dan Saîd b. el-Âs'ın görevden azledilmesini istemiştir. Süreç hakkında bilgi vermek üzere Saîd b. el-Âs da Medine'ye gelmiştir. Hz. Osman, Mâlik el-Eşter ve yanındakilerinin talebini reddetmiş ve onlara Kûfe'ye dönmelerini söylemiştir. İsteklerini halifeye kabul ettiremeyen Mâlik, Saîd'den önce Kûfe'ye gelmiş ve mescitte minbere çıkarak halka hitap etmiştir. Konuşmasında Saîd'in sevâd toprağını Kureyş'in malı gördüğünü, oysa bu bölgenin burada yaşayanların hakkı olduğunu ve babalarının mallarına sahip çımaları gerektiğini söylemiştir. Akabinde henüz Kûfe'ye giriş yapmayan Saîd'in Kûfe ile Hîre bölgesi arasında bulunan Ceraa denilen yerde karşılanarak şehre girmesine engel olunması gerektiğini bildirmiştir. Saîd b. el-Âs, Ceraa mevkiinde Mâlik'in kışkırttığı grupla karşılaşmış ve aralarında bir çatışma yaşanmıştır. Çok zor durumda kalan Sâid, Kûfe'ye giremeden Medine'ye dönmek mecburiyetinde kalmıştır. Mâlik askerleri ile tekrar Kûfe'ye döndüğünde minbere çıkmış, Allah'a hamd ettikten sonra kızgınlığının sadece Allah için olduğunu bildirmiştir. Akabinde Ebû Mûsâ el-Eş'arî̀yi (öl. 42/662) vali tayin ettiğini ve Huzeyfe b. el-Yemân'ı fey işlerinde görevlendirdiğini halka bildirmiştir. Daha sonra minbere çıan Ebû Mûsâ el-Eş‘arî bu durumun Hz. Osman'a danışılması gerektiğini ifade etmiştir. Olay Hz. Osman'a intikal ettirilmiş ve bu süreçte beyatlar yenilenmiştir. Hz. Osman bu neticeyi kabul etmiş ve Ebû Mûsâ el-Eş'arî Hz. Osman şehit oluncaya kadar bu görevinde kalmıştır. Huzeyfe b. el-Yemân'ı da ganimet görevinin başına tayin etmiştir. ${ }^{28}$ Ancak bu hâdise ve neticesinde Hz. Osman'ın onayı idarede zafiyetin olduğunu artık daha açık bir şekilde ortaya koymuştur. Çünkü halk, artık bu şekilde isyanların netice vereceğini düşünmeye başlamıştır. Bu durum, kaostan beslenenleri daha güçlü hale getirmiş, merkezi yönetim ve valilerin halk üzerindeki güç ve otoritesini zayıflatmıştır.

Ceraa günü Kûfe'de yaşanan bazı hâdiseler ile ilgili birtakım bilgiler kaynaklarda yer almaktadır. Burada dikkat çeken isim Hz. Peygamber'in sırdaşı Huzeyfe'dir. Zira o da bu bölgede görevlendirilmişti. O, birçok işte Sâid b. el-Âs ile birlikte hareket etmiştir. Ancak Sâid b. el-Âs, Kûfe'ye sokulmadığında Huzeyfe'nin nasıl bir tavır sergilediği merak konusudur. Kûfe'de insanlar Saîd b. el-Âs'ı azletmeye karar verdikten sonra başlarına kendilerine uygun birini vali atanması konusunda aralarında mektup yazdılar. Bu süreçte Medâin'den gelen Huzeyfe'nin yanına gittiler

${ }^{27}$ Ebû Abdillâh Muhammed b. Sa'd b. Menî‘ el-Kâtib el-Hâşimî el-Basrî el-Bağdâdî İbn Sa'd, et-Tabakātü’-Kübrâ, thk. Muhammed Abdülkadir Atâ (Beyrut: Dâru'l-Kütübi'l-illmiyye, 1990), 5/23; İbn Manzûr, Muhtasaru Târîhi Dımaşk, 9/306; İbn Kesîr, el-Bidâye ve'n-nihâye, 8/84; Zehebî, Siyeru a'lami'n-nübela, 3/445; Yıldız, Doğuştan Günümüze Büyük İslam Tarihi, 2/202-205.

28 İbn Sa'd, eț-Ṭabakātü'l-Kübrâ, 5/23-25; İbn Manzûr, Muhtasaru Târîhi Dımaşk, 9/307-308; Zehebî, Siyeru a lami’nnübela, 3/445; İbn Kesîr, el-Bidâye ve'n-nihâye, 8/84; Yıldız, Doğuştan Günümüze Büyük İslam Tarihi, 2/202-205. 
ve onun Saîd'in görevden alınması konusunda görüşünü de almak istediler. Huzeyfe onlara "Hakkınız olmayan bir topluluğun yönetimini mi üstlenmek istiyorsunuz?" diye bir soru yöneltmiş ve onlara bu girişimin fitne olduğunu bildirmiştir. ${ }^{29}$ Bir başka rivâyette ise Kûfeliler Saîd b. el-Âs'1 kovduklarında, mescitte oturmakta olan Huzeyfe ve Ebû Mes'ûd'un (öl. 42/662) yanına bir adam gelerek "İnsanlar ayaklanıp isyan başlatmışken siz niçin burada oturuyorsunuz? Vallahi biz doğru yoldayız." dediler. Onlar valilerini kovan kişilerin nasıl doğru yolda olabileceklerini söylemişlerdir. ${ }^{30}$ Muhtemelen Huzeyfe gibi bazı şahıslar fitne ateşi çok yükseldiğinden dolayı duruma müdahale edip Saîd b. el-Âs'a yardım edememişlerdir.

Saîd b. el-Âs, Kûfe'deki görevinden azledilince Medine'ye gelmiştir. Ancak kargaşa sona ermemiştir. Yeni bir fitnenin ateşi harlanmıştır. Zira Kûfe konusunda Hz. Osman'ın vermiş olduğu karar, otorite zafiyetini gün yüzüne çıkarmıştır. Buradan cesaret alan isyancılar, Hz. Osman'ın hilafetini tartışmalı hale getirmişlerdir.

\section{Hz. Osman'ın Şehit Edilmesi}

Hz. Osman'ın himayesinde büyüyen Saîd b. el-Âs, Medine'de yaşanan isyan sürecinde Hz. Osman'ın yanında bulunmuş ve onu korumaya çalışmıştır. Çocuk yaştan itibaren onun yanında olması aralarında daha yakın bir bağın kurulmasında etkili olmuştur. O, isyancı gruplarla savaşılması hususunda Hz. Osman'ı ikna etmeye çalışmıştır. Saîd, Hz. Osman'a “Onlar bize ok atıyorlar, kılıçlarını çektiler, bize taş firlatıyorlar, ne zamana kadar elimiz kolumuz bağlı duracağız neden savaşmıyoruz?" diyerek savaşma hususunda ondan müsaade almak istemiştir. Ancak Hz. Osman savaşmaktan kaçınmıştır. Bu süreçte kızgınlıkla dışarıya çıkan Saîd başına bir darbe almış ve yaralanmıştır. Daha sonraki dönemlerde gök gürültüsü olduğunda bu yaradan dolayı baygınlık geçirdiği rivâyet edilmektedir. ${ }^{31}$

Hz. Osman'ın şehit edilmesinden sonra onun intikamını almak üzere Talha (öl. 36/656), Zübeyr (öl. 36/656), Muğire b. Şube, Aişe ve Mervân b. el-Hakem (öl. 65/685) ile birlikte Saîd b. elÂs da Mekke'ye doğru yola çıkmıştır. Zât-ı ırk denilen yere geldiklerinde Saîd, orada bulunanlara bir konuşma yapmıştır. Konuşmasında Hz. Osman'ın faziletinden bahsetmiş ve ona duâ etmiştir. Daha sonra Müslümanlar arasında çıkacak olan bir tehlikenin ve ihtilafın farkına varmış, bu topluluk içerisinde bulunmayı doğru bulmayarak Taif'e gitmiş Cemel ve Sıffın savaşlarına da katılmamıştır. ${ }^{32}$ Her iki savaşta herhangi bir kesimin yanında bulunmayı uygun görmemiş ve tarafsız kalmıştır. Hz. Ali hayatta iken Emevî ailesine mensup olmasına rağmen Muâviye ile bir

29 İbn Ebî Şeybe, el-Musannef, 21/136.

30 İbn Ebî Şeybe, el-Musannef, 21/50.

31 İbn Manzûr, Muhtasaru Târîhi Dımaşk, 9/312; Zehebî, Siyeru a lami'n-nübela, 3/445-346.

32 İbn Sa'd, eț-Ṭabakātü'l-Kübrâ, 5/25-26; İbn Abdilberr, el-ìstî‘âb fì ma'rifeti'l-așhâab, 2/623; İbn Manzûr, Muhtasaru Târîhi Dımaşk, 9/308-310; Zehebî, Siyeru a'lami’n-nübela , 3/445-346; İbn Kesîr, el-Bidâye ve'n-nihâye, 8/85. 
yakın temas içerisine girdiğine dair bir malumat kaynaklarda tespit edilememiştir. Hz. Ali'nin şehit edilmesinden sonraki dönemde Taiften ayrılarak Şam'a Muâviye'nin yanına gitmiş, o da Saîd b. elÂs'1 Medine valisi olarak görevlendirmiştir.

\section{Medine Valiliği ve Vefatı}

Saîd b. el-Âs'ın ikinci valilik dönemi Muâviye döneminde Medine'de olmuştur. Muâviye siyasî mücadele sonucunda hakimiyeti tamamen eline alıp İslâm coğrafyasının tek gücü haline gelmiştir. Daha önce de belirtildiği üzere Saîd, Muâviye'nin siyasî mücadelesine iştirak etmemiş tarafsız kalmıştır. Hz. Ali'nin şehit edilmesinden sonra Muaviye'nin yanına gitmiştir. Şam'da dâr-1 naîm denen bir evi ve hammâm-1 naîm olarak isimlendirilen bir hamamı olduğu rivâyet edilmektedir. İlk zamanlarda kendi safında yer almadığından dolayı Muâviye onu kınamış ve ağır bir şekilde konuşmuştur. Bir müddet Şam'da kaldıktan sonra Medine'ye gönderilmiştir. O, iki kez Medine valiliği yapmıştır. İlk atamasında bir müddet görev yaptıktan sonra azledilmiş yerine Mervân b. Hakem vali olarak görevlendirilmiştir. Daha sonra Mervan azledilmiş, tekrar Saîd atanmıştır. Daha sonra yeniden Mervân görevi devralmıştır. Bu şekilde iki kez aynı kişi ile görev değişikliği olmuştur. ${ }^{33}$

Saîd, Muâviye tarafından Medine'ye vali tayin edildiğinde Ümeyye oğulları arasında bir çekişme yaşanmaktaydı. 0 , mevcut tartışmalar ve husumetin içinde bulunmayarak adaletli bir yönetim tarzı benimsemiştir. ${ }^{34}$ Medine'de valilik yaptığı dönemde, Hz. Ali ile ilgili kötü söz söylememiş, Ehl-i beyte karşı saygılı olmuş ve bu aileye karşı herhangi bir çirkin tavır içerisinde olmamıştır. Oysa Mervân görev yaptığı zamanlarda Hz. Ali hakkında ağır ifadeler kullanmış, hatta $\mathrm{Hz}$. Hasan ve Hz. Hüseyin'in bulunduğu mecliste dahi Ehl-i beyti yermiş ve lanetlemiştir. ${ }^{35}$ Ancak Saîd, Mervân gibi davranmamış, Ehl-i beytle yakın ilişki içinde olmak için Hz. Ali'nin kızı ve aynı zamanda Hz. Ömer'in eşi Ümmü Gülsüm ile evlilik yapmak istemiştir.

Medine'ye vali tayin edildiği ilk günlerde Saîd b. el-Âs, hem Ehl-i beyte mensup bir hanımla evlenmek hem de Hz. Ömer'i daha yakından tanımak için Hz. Ali'nin kızı Hz. Ömer’in dul kalan eşi Ümmü Gülsüm ile nikahlanmayı arzu etmiştir. Evlilik teklifine Ümmü Gülsüm sıcak bakmıştır. Ancak kardeşleri Hz. Hasan ve Hz. Hüseyin bu evliliğe rıza göstermemişlerdir. Bir başka rivâyete göre ise sadece Hüseyin bu evliliği hoş karşılamamıştır. Hal böyle iken evlilik hazırlığı yapılmış ve Ümmü Gülsüm'ün Hz. Ömer'den olma oğlu Zeyd nikah akdi için vekil tayin edilmiştir. Mehir olarak Saîd b. el-Âs yüz bin, başka bir rivâyete göre iki yüz bin dinar mehir göndermiştir.

33 İbn Sa'd, eț-Ṭabakātü'l-Kübrâ, 5/28-32, 118; İbn Manzûr, Muhtasaru Târîhi Dımașk, 9/309; Mizzî, Tehzî̉bü'l-Kemâl fî esmâ’i'r-ricâl, 10/503; Zehebî, Siyeru a'lami'n-nübela,3/445; İbn Kesîr, el-Bidâye ve'n-nihâye, 8/84-85.

34 İbn Manzûr, Muhtasaru Târîhi Dımaşk, 9/313.

35 Taberânî, el-Mu'cemu'l-kebîr, 3/85; İbn Manzûr, Muhtasaru Târîhi Dımaşk, 9/313; Zehebî, Siyeru a'lami'n-nübela, 3/447; İbn Kesîr, el-Bidâye ve'n-nihâye, 8/84. 
Ancak Hüseyin'in rıza göstermediğini anlayan Saîd, bu evlilik akdinden vazgeçmiş, mehri ise geri almayarak Ümmü Gülsüm'e bırakmıştır. ${ }^{36} \mathrm{Bu}$ tavrını, Ehl-i beyte karşı sevgi ve saygısının bir göstergesi olarak değerlendirmek mümkündür.

Saîd b. el-Âs, Medine'de valilik yaptığı dönemde Ümmü Gülsüm bnt. Ali ve oğlu Zeyd vefat etmiş, cenazede Hz. Hasan ve Hz. Hüseyin bulunmasına rağmen vali olması hasebiyle onların cenaze namazını kıldırmıştır. ${ }^{37}$ İbn Ömer, İbn Abbâs, Ebû Hureyre, Ebû Saîd, Ebû Katâde gibi seksen kadar sahabî de bu cenazede bulunmuştur. ${ }^{38}$

Saîd b. el-Âs, Hz. Hasan vefat ettiğinde onun da cenaze namazını kıldırmıştır. ${ }^{39}$ Üzüntüsünden dolayı ağladığı da rivâyet edilmektedir. ${ }^{40}$ Ancak Hz. Hüseyin ona "Şayet emirin öne geçip cenaze namazı kıldırması sünnet olmasaydı senin namaz kıldırmana müsaade etmezdim.” demiştir. ${ }^{41} \mathrm{~Hz}$. Hüseyin'in hem kardeşi Ümmü Gülsüm'ün Saîd ile evliliğine rıza göstermemesi hem de Hz. Hasan'ın cenaze namazının kıldırılması sürecinde Saîd b. el-Âs'a karşı takınmış olduğu tavrı farklı şekillerde okumak ve değerlendirmek mümkündür. Bu iki olaya bakıldığında Hz. Hüseyin'in Saîd b. el-Âs'tan hazmetmediğini söylemek mümkündür. Ancak kaynaklarda konu ile ilgili açık bir bilgi tespit edilemediğinden dolayı, söylenecek her şey sadece bir yorumdan ibaret olacaktır. Yukarıda da belirtildiği üzere Saîd b. el-Âs, Hz. Ali'ye karşı hayatı boyunca herhangi bir menfi bir davranış sergilememiştir. Hatta Ehl-i beyte evlilik vesilesiyle yakınlık kurmak istemiştir. Hz. Hüseyin'in duruşunu da farklı şekillerde değerlendirmek mümkündür. Öncelikle Hz. Hüseyin abisinin cenazesini kendisi kıldırmak istemiş olabilir. Ancak idareci durumunda olan kişinin bu görevi yapması sünnet olduğundan bunu yapamamıştır. İkincisi, Hz. Ali hayatta iken onun yanında yer almamasını kusur olarak görmüş veya Muâviye tarafından atanan bir valiyi Hz. Hüseyin bir türlü içine sindirememiş olabilir.

36 İbn Manzûr, Muhtasaru Târîhi Dimaşk, 9/313; Zehebî, Siyeru a'lami'n-nübela, 3/446-447; İbn Kesîr, el-Bidâye ve’nnihâye, 8/86.

37 İbn Ebî Şeybe, el-Musannef, 3/8, 7/293.

38 İbn Sa'd, eț-Ṭabakātü'l-Kübrâ, 8/340; Ebû Bekr Abdurrezzak b. Hemmâm es-San'ânî, el-Musannef, thk. Habibu'rRahman el-A‘zamî (Beyrut: el-Mektebetü'l-İslamiyye, 1983), 3/465; İbn Sa'd, eț-Tabakātü’l-Kübrâ, 8/340; Ebû Bekir Ahmed b. el-Hüseyin el-Beyhakî, es-Sünenü'l-kübra, 4/52; Ebû Bekir Ahmed b. el-Hüseyin el-Beyhakî, Ma'rifetü's-sünen ve'l-âsâr, 2/428; Ebû Bekr Muhammed b. İbrâhîm İbnü'l-Münzir en-Nîsâbûrî, el-Evsat fîs-sünen ve'l-icmâc ve'l-ihtilâf, thk. Ebû Hammâd Sağîr b. Ahmed b. Muhammed (Riyad: Dâru Taybe, ts.), 5/420.

39 Taberânî, el-Mu'cemu'l-kebîr, 3/26; Ebû Abdillâh Muhammed b. Abdillâh b. Muhammed el-Hâkim en-Nîsâbûrî, elMüstedrek, thk. Yûsuf Abdurrahman el-Ma'raşlî (Beyrut: Dâru'l-Ma'rife, ty.), 3/169.

40 Hâkim en-Nîsâbûrî, el-Müstedrek, 3/173.

${ }^{41}$ Taberânî, el-Mu'cemu'l-kebîr, 3/136; Ebû Bekir Ahmed b. el-Hüseyin el-Beyhakî, Ma'rifetü's-sünen ve'l-âsâr, thk. Abdulmu’tî Emîn Kal'acî (Beyrut: Dâru Kuteybe, 1991), 5/283; İbnü'l-Münzir, el-Evsat fîs-sünen ve'l-icmâc ve'lihtilâf, 5/399. 
Kaynaklarda yer alan bilgilere göre Saîd, Medine'de görev yaptığı süre içerisinde kendi kavmini kayırdığına dair bilgi bulunmamaktadır. Hatta Benî Ümeyye'den bir grup arasında yaşanan tartışmadan dahi uzak durmaya çalışmıştır. ${ }^{42}$

İnsanlar arasında adaleti ve güveni sağlama konusunda Hz. Ömer'i kendisine örnek aldığını söylemek mümkündür. Saîd b. el-Âs, Hz. Ömer hayatta iken onu yakından takip etmeye çalışmıştır. Bizzat kendisi şöyle anlatmaktadır: "Bir gece Ömer'i gözetledim. Seher vaktinde Bakî̀ye doğru çıktı. Onu takip ettim. O hızlandı ben de hızlandım. Bakı̂’e ulaştı ve namaz kıldı. Daha sonra elini açtı ve şöyle dedi: 'Allah'ım yaşım ilerledi, gücüm zayıfladı, halkımın dağılmasından korkuyorum, aciz düşmeden ve kınanmadan beni yanına al' dedi. Sabah oluncaya kadar böyle demeye devam etti." ${ }^{43} \mathrm{~Hz}$. Ömer'i yakından takip ettiğini söylemek mümkündür. Onu daha yakından tanımak için Hz. Ömer vefat ettikten sonra onun dul kalan eşleri ile de evlenme teşebbüsünde bulunmuştur. Ümmü Gülsüm ile ilgili girişimine yukarıda değinildi. Her ne kadar bu evlilik gerçekleşmese de o, Hz. Ömer'in bir başka eşi ile evlenmiştir. Evlendiği kadına, kadınlara olan isteğinden dolayı onunla evlenmediğini, Ömer'in hayatını anlatması için nikahlandığını söylemiştir. ${ }^{44}$

Medine valisi iken ashâbın ileri gelenleri ile istişare etmiş ve bazı konularda onların görüşlerine müracaat etmiştir. Mesela, Ebû Mûsa el-Eş'arî ve Huzeyfe b. el-Yemân'ın bulunduğu bir mecliste Hz. Peygamber'in kurban ve ramazan bayramlarında nasıl tekbir aldığını sormuş, Ebû Mûsâ cenaze namazındaki gibi dört tekbir alırdı diye cevap vermiştir. Huzeyfe de bunu onaylamıştır. ${ }^{45}$

Kendisine gelen davaların çözümünde farklı içtihatlarda bulunduğuna dair bazı bilgiler de aktarılmıştır. Ancak o genel kuralların dışına çıkmamıştır. Mesela Abdullah b. Ömer’in bir kölesi hırsızlık yapmış ve kaçmıştır. Daha sonra İbn Ömer, köleyi Medine valisi olan Saîl'e elinin kesmesi için göndermiştir. Sâid bundan ilk önce imtina etmiştir. "Hırsızlık yapıp kaçan kölenin elini kesmeyin." demiştir. İbn Ömer, "Bunu Allah'ın hangi kitabında buluyorsun" diyerek itiraz etmiş ve kölenin eli kesilmiştir. Burada İbn Ömer' in bir ısrarı dikkat çekmektedir. ${ }^{46}$ Bir diğer davada ise Saîd

${ }^{42}$ Ebû Bekr Abdullah b. Muhammed b. Ubeyd el-Kureşî el-Bağdâdî İbn Ebi'd-Dünyâ, el-İşrâf fî menâzili'l-eşrâf, thk. Necm Abdurrahman Halef (Riyad: Mektebetü’r-Rüşd, 1990), 231.

43 Ma'mer b. Râşid el-Basrî es-San ‘̂nî, el-Câmi’, thk. Habiburrahman el-A'zâmî (Beyrut: Mektebetü’l-İslamiye, 1403), 11/315.

44 Ebû Bekir Ahmed b. el-Hüseyin el-Beyhakî, Şu'abu'l-imân, thk. Abdulali Abdulhamîd Hâmid (Beyrut: Mektebetü'r-Rüşd, 2003), 6/391.

45 Ahmed b. Hanbel, el-Müsned, 32/510; Ebû Dâvûd, "Salât", 251; Taberânî, el-Mu'cemu'l-kebîr, 9/104; Beyhakî, esSünenü'l-kübra, 3/408-409; İbnü'l-Münzir, el-Evsat fìs-sünen ve'l-icmâ‘ ve'l-ihtilâf, 4/275.

46 Ebû Abdillâh Mâlik b. Enes el-Asbahî, Muvatta, thk. Muhammed Mustafa el-A'zami (Abu Dabi: Devletü'lEmarati'l-Arabiyyeti'l-Müttahide, 2004), 5/1219; Abdurrezzak b. Hemmâm, el-Musannef, 10/240; İbn Ebî Şeybe, el-Musannef, 14/380; Beyhakî, es-Sünenü'l-kübra, 8/466; Beyhakî, Ma'rifetü's-sünen ve'l-âsâr, 12/406. 
b. el-Âs, hataen öldürülen kölenin diyetini dört bin olarak belirlemiştir. Ancak kölenin değeri bundan çok daha fazlaymış. O, bir kölenin diyetinin bir hürden daha fazla olmasını hoş görmüyorum demiştir. Burada onun bir içtihadını da görmek mümkündür. ${ }^{47}$ Yine başka bir rivâyette Saîd b. el-Âs öğle veya ikindi namazını kıldırırken kıraatı unutarak cehrî okumuş, orada bulunanlar "sübhanallah" demişler. Ancak o cehrî okumaya devam etmiştir. Daha sonra minbere çıkıp cehrî başladığından dolayı Kur'ân'ı tekrar gizli okumayı hoş görmediğini belirtmiştir. Sehv secdesi de yapmamıştır. Bu namazda ashâbtan çok sayıda kişi olmasına rağmen herhangi bir itiraz olmamıştır. ${ }^{48}$

Yukarıda yer alan örneklerden anlaşılacağı üzere ashâb-1 kirâmın bulunduğu bir ortamda yanlış bir uygulama varsa ve vali de uyumlu bir kimse ise düzeltilmiştir. Abdullah b. Zübeyr ile kardeşi Amr arasında yaşanan bir husumet buna örnek olabilir. Abdullah, Sâid'in yanına vardığında kardeşinin onun yanında sedirde oturduğunu görmüştür. Sâid, Abdullah'a "Buraya buyur." demiștir. Ancak Abdullah, Rasûlullah'ın hükmünün/sünnetinin böyle olmadığını, iki hasmın hâkimin önünde oturması gerektiği söylemiştir. $\mathrm{O}$ da bunu hemen uygulamıştır. ${ }^{49}$

Medine'de görev yaptığı süre içerisinde insanların her türlü sorunları ile ilgilenmiştir. Hatta Muâviye'ye kendisinden sonra yönetim kimin eline geçecektir şeklinde bir soru yöneltildiğinde o Saîd b. el-Âs, Abdullah b. Amir, Hasan b. Ali, Mervân b. Hakem, Abdullah b. Ömer, Abdullah b. Zübeyr şeklinde saymış olduğu isimler arasında ona da yer vermiştir. Onu Kureyş’in âl-i cenâbı olarak vasfetmiştir. ${ }^{50}$ Yani o dönemde potansiyel bir halife adayı olarak dahi görülmüştür. Fakat onun vefatında yaklaşık on yıl geçince Muâviye farklı bir tercihte bulunarak oğlu Yezid'i kendisinden sonra halife tayin etmiştir.

Saîd b. el-Âs, hicrî elli sekiz veya elli dokuz senesinde Medine'ye üç mil uzaklıkta bulunan Arbasa'daki evinde/çifliğinde vefat etmiş ve Bakî kabristanına defnedilmiştir. ${ }^{51}$ Ebû Hureyre, Hz. Aişe ve Sa d b. Mâlik de bu yıl dâr-1 bekaya irtihal etmiştir. ${ }^{52}$ Vefatından sonra oğlu Amr b. Saîd b. el-Âs, babasının borcunu ödemek üzere Arbasa'da bulunan evini ve bostanlarını üç yüz bin

47 İbn Ebî Şeybe, el-Musannef, 14/132.

48 İbn Ebî Şeybe, el-Musannef, 3/244; İbnü'l-Münzir, el-Evsat fís-sünen ve'l-icmấ ve'l-ihtilâf, 3/302; Ebû Muhammed Alî b. Ahmed İbn Hazm el-Endelusî, el-Muhallâ bi'l-Âsâr, thk. Abdulğaffâr Süleyman el-Bundârî (Beyrut: Dâru'lFikr, 2002), 3/26; Beyhakî, es-Sünenü'l-kübra, 2/490.

${ }^{49}$ Ahmed b. Hanbel, el-Müsned, 26/29; Taberânî, el-Mu'cemu'l-kebîr, 13/103; Hâkim en-Nîsâbûrî, el-Müstedrek, 4/94.

50 Ebû Bekr Ahmed b. Amr b. ed-Dahhâk İbn Ebî Âsım eş-Şeybânî, el-Âhâd ve'l-mesânî (Riyad: Dâru'r-Râye, 1991), 1/393; İbn Manzûr, Muhtasaru Târîhi Dımaşk, 9/309-310; 9/309-310 Tehzibu'l-kemâl, 10/502; Zehebî, Siyeru a'ami'n-nübela, 3/446; İbn Kesîr, el-Bidâye ve’n-nihâye, 8/85.

51 Zehebî, Siyeru a'lami'n-nübela, 3/448.

52 Hâkim en-Nîsâbûrî, el-Müstedrek, 3/507. 
dirheme Muâviye'ye satmıştır..$^{53}$ Aslında o, maddî durumu kötü olan biri değildi. Borçları daha çok sehâvetinden kaynaklanmakta idi. Saîd b. el-Âs hayatı boyunca, cömertliği ve başkalarına ikram etmeyi yaşam prensibi haline getirmiştir.

\section{Cömertliği ve Ahlâkı}

Saîd b. el-Âs, kendisinden bir şey talep edenleri geri çevirmemiştir. Eğer yanında yeterli miktarda bir parası yoksa bir belge yazdırmış daha sonra söz verdiği parayı ödemiştir. Çok cömert olduğundan dolayı ukkatü'l-asel (bal tulumu) olarak isimlendirilmiştir. ${ }^{54}$

Bir gün Medine sokaklarının birinden geçerken bir evden su istemiş ve kendisine su verilmiş, verilen suyu içmiştir. Bu esnada kendisine su veren adamın, evini satılığa çıkardığını öğrenmiş ve bunun sebebini sormuştur. Adam, 4000 dinar borcu bulunduğu için satmak istediğini söyleyince, Saîd adamın alacaklısına haber göndererek: "Alacağın bana ait, ben sana ödeyeceğim." söylemiştir. Ev sahibine haber göndererek: "Evini satma. Dilediğin gibi evinde otur." demiştir. ${ }^{55}$

Onun cömertliği ifade eden şöyle bir rivâyet daha aktarılmaktadır: Meclisinde bulunan kurrâlardan biri fakirlikten dolayı muhtaç duruma düşmüştür. Karısı ona, durumlarını valiye yani Saîd'e bildirmelerini söylemiştir. Bu kişi utancından dolayı halini gidip anlatmaktan imtina etmiştir. Eşinin ısrarı üzerine valinin makamına girmiştir. Bir şeyler talep etmek için geldiğini anlayan Saîd, orada bulunanları dışarıya çıkarmış ve adam arzusunu rahat ifade etsin diye kandili de söndürmüştür. Muhtaç kişi çok yoksul düştüğünü ve maddî durumunun kötü olduğunu arz etmiştir. Bunun üzerine Saîd ona sabah olunca vekilinin yanına gitmesini bildirmiştir. Ertesi gün bu kişi vekilin yanına gitmiş ve Saîd'in gönderdiğini söylediğinde, vekil eşyaları taşıyabilmesi için bir iki adam bulup getirmesini ondan talep etmiştir. Eşyaları taşıyacak kişi bulamayan bu fakir zat, evine gelerek hanımına kızmış ona, "Beni ne hallere düşürdün. Bana biraz un ve gıda verecekler bunun için adam istediler, para verecek olsalardı hamala ihtiyaç olmazdı." demiştir. Eşi, olsun ona da ihtiyacımız var, gidip eşyaları almasını istemiştir. Adam eşyaları almaya gittiğinde vekil ona "Eşyalarını seninle birlikte taşıyacak kimsen olmadığını valiye bildirdim. O da şu üç Sudanlıyı eşyaları taşımak için gönderdi." söylemiştir. Bu fakir zat eşyalar eve taşındığında her bir kişinin başının üzerinde 10.000 dirhem olduğunu görünce çok şaşırmıştır. Sudanlı hizmetçilere eşyaları indirdikten sonra gidebilecekleri söylemiş, fakat onlar kendilerinin vali tarafından armağan edildiğini belirtmişlerdir. ${ }^{56} \mathrm{Bu}$ örnek onun cömertlikte ne kadar yüksek bir konumda olduğunu göstermektedir.

53 Zehebî, Siyeru aclami'n-nübela, 3/448.

54 İbn Abdilberr en-Nemerî, el-İstî́âb fî ma'rifeti'l-așhâb, 2/623; İbn Manzûr, Muhtasaru Târîhi Dımaşk, 9/313; Zehebî, Siyeru a'lami'n-nübela, $3 / 447$.

55 Zehebî, Siyeru a'lami'n-nübela, 3/347; İbn Kesîr, el-Bidâye ve'n-nihâye, 8/84.

56 İbn Kesîr, el-Bidâye ve'n-nihâye, 8/85-86. 
Başka bir rivâyette ise, bir Bedevî ondan yardım istemiştir. O da bu kimseye 500 dirhem verilmesini emretmiştir. Görevli olan hizmetçi "Dirhem mi? dinar mı?" diye sorduğunda "Dirhem demiştim, ancak gönlünden kopan dinarsa onu ver." diye emretmiştir. Bunu duyan fakir bedevî ağlamaya başlamıştır. Ağlamasının sebebi sorulduğunda, onun gibi bir kişinin cesedini toprağın nasıl çürüteceğini aklının almadığını söyleyerek Saîd'in cömertliği karşısında hissettiği duyguları ifade etmiştir. ${ }^{57}$

Yine rivâyet edildiğine göre, adamın biri, ödemesi gereken dört diyetin parasını toplamak üzere Medine'ye gelmiş, Saîd b. el-Âs'a giderek ihtiyacını arz etmiştir. Saîd ona mal taşıyacak birini getirmesini söylemiştir. Adam bu sözün üzerine paraya ihtiyacının olduğunu hurmaya ihtiyacının olmadığını bildirmiştir. Saîd, ona 40.000 dinar gibi büyük bir meblağ verince neden taşıyıcıya ihtiyacı olduğunu anlamıştır. ${ }^{58}$

Saîd b. el-Âs'ın ihtiyaç sahibi olmayan kişilere dahi ikram etmekten hoşlandığı rivâyet edilmektedir. Saîd bir gün mescide doğru yalnız başına yürürken Kureyşli biri kalkıp onun sağında yürümeye başlamıştır. Said'in evinin önüne geldiklerinde ona neye ihtiyacı olduğunu sormuştur. Adam, "Bir şeye ihtiyacım yok, sadece sana eşlik ettim" demiştir. Saîd kahyası Ebû Ka'b'a yanında ne kadar var demiş, o da üç bin dinarın var olduğunu belirtmiştir. Saîd, dinarların bu adama verilmesini istemiştir. ${ }^{59}$

O, insanlara bir şey vereceği zaman onları utandırmamaya da özen göstermiş, "Eğer ben çok açık ve bariz bir şekilde istendikten sonra vereceksem, ona vereceğim ondan alınanı (mahcubiyeti) karşılayamaz." demiştir. ${ }^{60}$ Ayrıca mescitte namaz kılmakta olan ihtiyaç sahiplerinin önünde para keseleri bırakmıştır. ${ }^{61}$

Kendisine gelen hediyeleri dahi çevresindekilere dağıtmıştır. Rivâyet edildiğine göre, Ziyâd b. Ebî Süfyan'ın (öl. 53/673) kendisine gönderdiği bir miktar mal ve hediyeleri meclisinde oturan kişilere vermiştir. ${ }^{62}$ Bazen vali olarak bu tür harcamaları onun görevden alınmasına dahi sebep olmuştur. Mesela, Medine'de valilik yaptığı dönemde, yaşanan bir kıtlık sebebiyle beytü’l-malı

57 İbn Abdilberr, el-İstî́âb fì márifeteti'-așhâb, 2/623-624; İbn Manzûr, Muhtasaru Târîhi Dimaşk, 9/314; ỉbn Kesîr, elBidâye ve'n-nihâye, $8 / 86$.

${ }^{58}$ Ebû Bekr Abdullah b. Muhammed İbn Ebi'd-Dünyâ el-Bağdâdî, Mekârimü'l-ahlâk, thk. Mecdî es-Seyyîd ỉbrâhîm (Kahire: Mektebetü'l-Kur'ân, ty.), 135; ỉbn Kesîr, el-Bidâye ve'n-nihâye, 8/86.

59 İbn Ebi'd-Dünyâ, Mekârimü'l-ahlâk, 113.

60 Ebû Bekr Abdullah b. Muhammed b. Ubeyd el-Kureşî el-Bağdâdî ìbn Ebi'd-Dünyâ, Kadâu'l-havâici, thk. Muhammed Abdülkadir Ahmed Atâ (Beyrut: Müessesetü'l-Kütübi's-Sekâfiyye, 1993), 43.

${ }^{61}$ İbn Manzûr, Muhtasaru Târîhi Dımaşk, 9/313-314; ỉbn Kesîr, el-Bidâye ve'n-nihâye, 8/84.

62 ỉbn Kesîr, el-Bidâye ve'n-nihâye, 8/86. 
seferber etmiş, hazinedeki mallar tamamen tükenince Muâviye onu görevden almıştır. ${ }^{63}$

O, alış-veriş esnasında karşı tarafı koruyup kollamayı ihmal etmemiştir. Medine'de Zurayk oğullarına mensup Ebü'l-Mualla ailesinden bir ev satın almıştır. Bu aile daha sonra evi geri almak istemiş, o da evi geri iade etmiştir. Sonra bu kimseler tekrar pişman olmuşlar, yeniden satmak istediklerinde ise Saîd onlara fazladan yüz bin göndermiştir. ${ }^{64}$

Saîd b. el-Âs, dostlarına karşı çok hassas davranmıştır. Dostları ile ilgili şöyle demiştir: "Dostumun benim üzerimde üç hakkı vardır: Bana geldiğinde onun için ortamı geniş tutarım. Oturduğunda ona yönelirim. Konuştuğunda onu dinlerim. ${ }^{15}$ Her Cuma komşularını ve dostlarını davet etmiş, onları yedirmiş, içirmiş ve giydirmiştir. Ayrılacakları zaman onlara hediyeler vermiştir. ${ }^{66}$

Cömertliği ile temayüz eden Saîd b. el-Âs, insanlar ile olan münasebetini de şöyle izah etmiş̧ir: "Kendimi bir adam olarak bildiğimden beri kimseye sövmedim, dizimle de dahi olsa eziyet maksadıyla kimsenin dizini itmedim. Beni ziyarete geleni ben de ziyaret ederim. Bunu o kadar ciddiye alırım ki o kişi, içine konulan sudan dolayı terleyen kap gibi alnı terleyinceye kadar ziyarette bulunurum. Allah'a yemin ederim ki böyle yapmadığım takdirde kendimi ihmalkâr sayarım." ${ }^{67}$ Bu durum onun ahlakî hassasiyetini en iyi bir şekilde özetlemektedir. Başta cömertlik olmak üzere bu tür ahlâkî meziyetler onun insanlar arasında sevilmesine ve sayılmasına sebep olmuştur. Onun hakkında Ferezdak (öl. 114/732) şöyle demiştir:

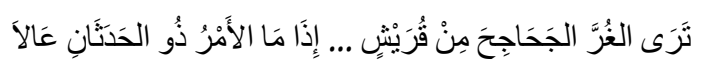

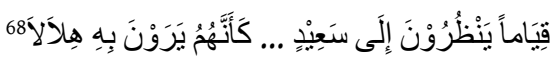

"Gece ve gündüz işin hedeften saptığı esnada, Kureyş̧in önde gelen şahsiyetlerinin durup Saîd'e baktıklarını görürsün. Onlar sanki Saîd’te hilali görüyorlar.”

63 İbn Manzûr, Muhtasaru Târîhi Dımaşk, 9/315; Zehebî, Siyeru a lami’n-nübela, 3/447.

64 İbn Ebi'd-Dünyâ, Mekârimü'l-ahlâk, 108.

${ }^{65}$ Ebû Bekr Muhammed b. Ca'fer b. Muhammed es-Sâmerrî el-Harâitî, Mekârimü'l-ahlâk ve méâlihhâ, thk. Eymen Abdulcâbir el-Buheyrî (Kahire: Dâru'l-Âfâk, 1999), 237.

66 Ebû Bekr Abdullah b. Muhammed b. Ubeyd el-Kureşî el-Bağdâdî İbn Ebi'd-Dünyâ, el-i̇hvân, thk. Mustafa Abdulkadir Atâ (Beyrut: Dâru'l-Kütübi'l-i̇lmiyye, 1988), 244-246.

67 Ebû Bekr Abdullah b. Muhammed b. Ubeyd el-Kureşî el-Bağdâdî İbn Ebi'd-Dünyâ, el-Hilm, thk. Muhammed Abdülkadir Ahmed Atâ (Beyrut: Müessesetü'l-Kütübi's-Sekâfiyye, 1413), 74.

68 Zehebî, Siyeru a'lami'n-nübela, 3/445; İbn Kesîr, el-Bidâye ve'n-nihâye, 8/84.

$\overline{54} \quad$ Journal of Eskişehir Osmangazi University Faculty of Theology 
Saîd b. el-Âs, yaptığı iyiliklerden dolayı insanların duâsını almıştır. Bir gün ikramda bulunduğu bir kadın ona gelerek şöyle demiştir: "Allah, seni namerde muhtaç etmesin, onurlu kimselere karşı da lütfunu devam ettirsin ve hep onları senin minnetin altında bıraksın. Şerefli bir kimsenin elindeki bir nimeti Cenâb-1 Allah giderdiği zaman o nimeti o şerefli kimseye geri vermek için seni sebep k1lsın." ${ }^{\prime 9}$

Rivâyete göre, Saîd b. el-Âs vefat ettiğinde Muâviye, Saîd'in oğlu Amr'a "Senin gibi bir evladı geride bırakan kimse ölmüş sayılmaz. Allah, Ebû Osman'a (babana) rahmet etsin, gerçekten de yaşça benden küçük ama rütbece benden büyük olan bir kimse vefat etti." demiştir. ${ }^{70}$

Saîd b. el-Âs'ın kız ve erkek olmak üzere toplam on çocuğu olmuştur. Amr, Muhammed, Abdullah, Osman, Ebân, Utbe, Yahya isimli çocuklarının olduğu kaynaklarda yer almaktadır. ${ }^{71} \mathrm{O}$, çocuklarına hitaben özel bazı nasihatlerde bulunmuştur. Ahlâkî içerikli olan bu öğütler bir sonraki başlıkta ele alınacaktır.

\section{Nasihatleri ve Hadîs Rivâyeti}

Saîd b. el-Âs, sahabî olması hasebiyle onun sözleri mevkûf hadîs olarak değerlendirilmektedir. Kaynaklarda doğrudan çocuklarına hitaben "Ey oğulcuğum!" hitap cümlesi ile başlayan öğütleri bulunmaktadır. Çocuklarının terbiyesine ve yetişmesine özen göstermiştir. Konu ile ilgili olarak şöyle demiştir: “Çocuğuma Kur'ân’ı öğrettiğim, hacc ettirdiğim ve evlendirdiğim zaman hakkını vermiş olurum ve benim onda hakkım kalmış olur." ${ }^{72}$ Tespit edilebildiği kadarıyla evlatlarına nasihatleri şöyledir:

"Ey oğulcuğum, Allah için iyilik yap, senden istenmeden sen ver. Bir adam yüzü kızarmış, âdeta kan başına sıçramış ya da kendisine verip vermeyeceğini bilmediği için tereddüt içinde iken sana gelirse, vallahi sen ona malının tamamını versen bile onun bu haline denk bir iyilikte bulunmuş olamazsın. Benim meclisimde oturacak olan kimseler üçtür: Biri, yaklaştığında kendisine merhaba dediğim ve yer gösterdiğim kimsedir. Biri de meclisimde oturduğunda kendisine yerini genişlettiğim kimsedir. Biri de konuştuğumda kendisine yöneldiğim ve dinlediğim kimsedir." ${ }^{73}$

“Yavrucuğum! Güzel ahlâk çok kolay olsaydı, kötüler onda sizi geçerlerdi. Fakat güzel ahlâk

69 İbn Kesîr, el-Bidâye ve'n-nihâye, 8/86-87.

70 İbn Kesîr, el-Bidâye ve'n-nihâye, 8/86-87.

71 İbn Abdillâh, el-İstî‘âb fî ma'rifeti'l-așhâb, 2/623. Bu kaynakta Amr değil de Ömer yazıll.

72 İbn Ebî Şeybe, el-Musannef, 13/416; Beyhakî, es-Sünenü'l-kübra, 3/120.

73 İbn Abdilberr en-Nemerî, el-İstî̀âb fì ma'rifeti'l-aṣhâb, 2/92. 
acıdır, hoşa gitmez; ona ancak sevabını Allah'tan uman ve faziletini bilenler sabreder." ${ }^{74}$

"Ey oğulcuğum! Soylu ve şerefli olanla şakalaşıp laubali olma, senden nefret eder. Aşağıllk ve şerefsizle şakalaşma, sana karşı cüretkâr olur." ${ }^{\text {T5 }}$

Saîd, vefat edeceği zaman çocuklarını topladı ve onlara şöyle dedi: "Arkadaşlarım sadece benim yüzümü görmekten mahrum kalacaklar, onlara hayatta iken nasıl davrandıysam, siz de öyle davranın. Aradaki dostluk bağlarımı koparmayın. Onlara yaptığım iyilikleri sürdürün, ihtiyaçlarını giderin. Bir kişi ihtiyacını gidermek için birisinden bir talepte bulunduğu zaman vücudu sarsılır, eklemleri tir tir titrer ve reddedilmekten korkar. Allah'a yemin ederim ki, sizi ihtiyacını giderecek kimseler olarak gören bir adamın kendi yatağında kıvranması, sizin ona vereceğiniz yardımdan ve bahşedeceğiniz ikramdan sizin için daha büyük bir minnettir. Onlar, sizden istemeye gelmeden önce ihtiyaçlarını giderin." Saîd böyle dedikten sonra çocuklarına daha birçok vasiyetlerde bulunmuştur. Mesela, borçlarını ödemelerini, verdiği sözleri yerine getirmelerini, kız çocuklarını denkleri olan kimselerden başkalarıyla evlendirmemelerini, büyüklerini başlarına lider yapmalarını vasiyet etmiştir. Bu vasiyetlerinin yerine getirilmesini oğlu Amr b. Saîd el-Eşdak (öl. 70/690) üstlenmiştir. ${ }^{76}$

Hadîs kaynaklarında onun merfu olarak nakletmiş olduğu hadîsler de bulunmaktadır. Ancak o, Rasûlullah vefat ettiğinde takriben dokuz yaşında olduğu için Hz. Peygamber ile uzun süre vakit geçirme imkânı elde edememiştir. Tespit edilebildiği kadarıyla yirmi civarında hadîs rivâyet etmiştir. Bu rivâyetlerin bir kısmı da sahabî mürselidir. Hz. Peygamber dışında Hz. Ömer, Hz. Osman ve Hz. Aişe'den hadîs nakletmiştir. Oğulları Amr b. Saîd el-Eşdak ile Ebû Saîd, Urve b. Zübeyr, Salim b. Abdullah vd. ondan hadîs almışlardır. ${ }^{77}$

Saîd b. el-Âs, aracılığıyla nakledilen hadîslerin bir kısmı ise şöyledir: "Hiçbir baba, evlâdına güzel terbiyeden daha üstün bir hediye vermemiştir", ${ }^{88}$ "Büyük kardeşin küçük kardeşler üzerindeki hakkı, anne babanın çocukları üzerindeki hakkı gibidir", ${ }^{79}$ Osman b. Maz'ûn Rasûlullah'a (s.a.s.) "Ey Allah'ın Rasûlü! Bana hadım olma hususunda izin ver” demiş. Bunun üzerine Hz. Peygamber "Ey Osman! Allah ruhbanlığa karşllık bize müsamahakâr bir Hanifliği bahşetti. Tekbir, bütün şereflerin üstündedir. Sen bizden isen bizim gibi yap", ${ }^{80}$ "Rasûlullah (s.a.s.)

74 İbn Ebi'd-Dünyâ el-Bağdâdî, Mekârimü'l-ahlâk, 30; Beyhakî, Şu'abu'l-imân, 11/63.

75 Ebû Bekr Abdullah b. Muhammed b. Ubeyd el-Kureşî el-Bağdâdî İbn Ebi'd-Dünyâ, es-Samt, thk. EbûIshâk elHuveynî (Beyrut: Dâru'l-Kitâbi'l-Arabî, 1410), 211.

76 İbn Ebi'd-Dünyâ, el-i̇hvân, 223; İbn Kesîr, el-Bidâye ve'n-nihâye, 8/86-87.

77 Mizzî, Tehzî̉bü’l-Kemâl fî esmẩi'r-ricâl, 10/502; Zehebî, Siyeru a'lami’n-nübela, 3/445.

78 Ahmed b. Hanbel, el-Müsned, 24/128; Tirmizî, "Birr", 33; Hâkim en-Nîsâbûrî, el-Müstedrek, 4/263.

79 Beyhakî, Şu'abu'l-imân, 11/313.

80 Taberânî, el-Mu'cemu'l-kebîr, 6/62. 
Mekke'den çıktığında Akîk ve Zî Tuvâ mevkiinde namazı kısaltırdı", ${ }^{81} \mathrm{~Hz}$. Aişe'nin yanında Ramazan ayının yirmi dokuz gün olduğu zikredildi. O, buna şaşırdı ve şöyle dedi: Bunda neden şaşırdınız. Rasûlullah (s.a.s.) ile otuz günden daha fazla yirmi dokuz gün oruç tuttum" ${ }^{82}$ gibi hadîsler onun aracilığı ile nakledilmiştir. ${ }^{83}$

\section{Sonuç}

Bu makalede İslâm tarihinde önemli bir yere sahip olan Saîd b. el-Âs'ın hayatı; dinî, ilmî ve siyâsî yönü incelenmiştir. Hicret yılında dünyaya gelen Saîd b. el-Âs çocuk yaşta babasını kaybetmiş, yakın akrabalarından biri olan Hz. Osman'ın himayesinde büyümüştür. Hz. Osman şehit edilinceye kadar onun en yakınında biri olmuştur. Güçlü ve dirayetli duruşu sayesinde genç yaşından itibaren önemli görevlerde istihdam edilmiştir. Ermenistan ve Azerbaycan'a seferlerinde ordu komutanı; Kûfe ve Medine gibi stratejik öneme sahip şehirlerde vali olarak görev yapmıştır. Kur'ân-1 Kerim'in istinsah heyetinde üstlenmiş olduğu sorumluluk ise hiç şüphesiz onun en önemli görevlerinden biri olmuştur. Bu çalışma neticesinde Saîd b. el-Âs ile ilgili elde edilen sonuçları şöyle sıralamak mümkündür:

Saîd b. el-Âs'ın babası Bedir savaşında müşriklerin safında iken Hz. Ali tarafından öldürülmüsstür. Bu sebepten dolayı Hz. Ali'ye karşı bir kırgınlığı veya husumeti olduğuna dair herhangi bir tavrı tespit edilememiştir. Bilakis Kûfe'de valilik yaptığı dönemde Hz. Ali'ye özel hediyeler göndermiştir. Medine'de valilik yaptığı zamanda ise Muâviye'nin iktidar dönemi olmasına rağmen Ehl-i beyte karşı bir saygısızlık içerisinde olmamıştır. Ayrıca Hz. Ali'nin kızı Ümmü Gülsüm ile nikahlanmayı dahi arzu etmiştir.

Medine'de görev yaptığı dönemde Hz. Hasan ve Hz. Hüseyin ile iyi ilişkiler içerisinde bulunmuştur. Bu kişileri üzmemeye gayret etmiştir. Zira Ümmü Gülsüm ile evlenmesine $\mathrm{Hz}$. Hüseyin rıza göstermediğinden dolayı mehir vermiş olmasına rağmen nikahtan vaz geçmiştir. Bu

81 Ebû Dâvûd Süleymân b. el-Eş‘as b. İshâk es-Sicistânî el-Ezdî, el-Merâsîl, thk. Şuayb Arnâût (Beyrut: Müessesetü’rRisale, 1408), 110; Ebû Abdillâh Muhammed b. İshâk b. Abbâs el-Fâkihî, Ahbâru Mekke (Beyrut: Dâru Hader, 1414), 4/70.

82 Ebû Dâvûd Süleymân b. Dâvûd b. el-Cârûd et-Tayâlisî, el-Müsned, thk. Muhammed b. Abdilmuhsin et-Türkî (Misır: Dâru Hacer, 1994), 3/134.

83 Saîd b. el-Âs aracilı̆̆ı ile nakledilen diğer hadisler için bk. Ahmed b. Hanbel, el-Müsned, 1/538; Buhârî, "Menâkıb", 22; Ebû Abdillâh Muhammed b. İsmâîl b. İbrâhîm el-Cu'fî el-Buhârî, el-Edebü'l-Müfred, thk. Muhammed Fuâd Abdulbâkî (Beyrut: Dâru'l-Beşâiri'l-İslâmiyye, 1989), 210; Ebü'l-Hüseyn Müslim b. Haccâc Müslim, Sahihu Müslim (Riyad: Dâru Tîbe, 2006), “Fedâilu's-Sahabe”, 27; Ebû Bekr Ahmed b. Amr b. Abdilhâlik elBezzâr el-Basrî, Müsnedü'l-Bezzâr, thk. Mahfûz Abdurrahmân Zeynullah (Medine: Mektebetü'l-Ulûm Ve'l-Hikem, 1988), 1/443; Taberânî, el-Mu'cemu'l-kebîr, 6/61-62; Ebû Bekir Ahmed b. el-Hüseyin el-Beyhakî, Delâilu'n-nübüvve (Beyrut: Dâru'l-Kütübi'l-İlmiyye, 1988), 6/465; İbn Manzûr, Muhtasaru Târîhi Dımaşk, 9/305; İbn Kesîr, el-Bidâye ve'n-nihâye, 8/84. 
tavrı, Ehl-i beyte göstermiş olduğu saygından ileri geldiğini söylemek mümkündür. Hz. Hüseyin'in bu evliliği onaylamamasının asıl sebebi ise tam olarak tespit edilememiştir. Muâviye'nin valisi olması, Cemel ve Sıffın savaşlarında tarafsız kalması, Emevî ailesine mensup oluşu vs. gibi hususlar ihtimal dahilindedir. Ancak kesin bir şey söylemek mümkün değildir.

Büyük sahabîlerin bulunduğu ordularda komutanlık yapmış, dinî, ilmî ve siyasî meselelerde tecrübeli kişilerin görüşlerine müracaat etmiş̧ir. Bu davranışı onun istişareye öneme verdiğini göstermektedir.

Kur'ân nüshalarının çoğaltılması için teşekkül ettirilen heyetin içinde bulunmuştur. Kur'ân bilgisi, Arap diline olan hakimiyeti, beliğ ve fasih dil becerisi, lehçesinin Hz. Peygamber'e benzemesi gibi meziyetlerinden dolayı bu komisyonda istihdam edilmiştir. Heyetteki asıl görevi ise kelimelerin doğru yazımı ile ilgili olmuştur. Birkaç örnek dışında hangi sûrelerde, âyetlerde ve kelimelerde ihtilaf edildiği ve bu komisyonun üstlenmiş olduğu sorumluluğu ne kadar süre içerisinde tamamladığı tam olarak tespit edilememiştir. Sadece savaşlar ve valilerin görev sürelerindeki tarihler dikkate alınarak hicrî 26-30 yılları arasında Kur'ân'ın istinsah edildiği sonucuna varılmıştır. Bu çalışma öncesinde Saîd b. el-Âs üzerinde istinsah heyeti ile ilgili geniş bir malumat elde edilebileceği düşünülmüş, ancak konu ile ilgili sınırlı bilgiye ulaşılmıştır.

Kûfe'de görev yaptığı süre içerisinde sert bir yönetim tarzı benimsediği görülmüştür. Kaos ve kargaşanın eksik olmadığı bu şehirde düzeni sağlamakta zorlanan Saîd, görevden alınmıştır. Onun valilikten azledilmesi Hz. Osman'ın da otoritesini sarsmış ve hilafetinin sona doğru gelmesine zemin hazırlamıştır. Cemel ve sıffın savaşlarında tarafsız kalmak suretiyle Müslümanların birbirleriyle çatışmasını hoş görmediği anlaşılmaktadır.

Yönetim tarzı olarak Hz. Osman'dan ziyade Hz. Ömer'i kendisine rehber edinmeye çalışmıştır. Hz. Ömer'i hayatta iken onu takip etmiş ve vefatından sonraki süreçte dul kalan eşleri ile evlenmeyi isteyerek dolaylı olarak da olsa onu daha yakından tanımaya çalıștı̆̆ı tespit edilmiştir.

Cömertliği ile meşhur olmuştur. Özellikle Medine'de görev yaptığı sırada ihtiyaç sahiplerine yüklü miktarda para verdiği görülmüştür. Tasadduk ettiği dirhem ve dinarların bir kısmı abartı gibi görünse de konu ile ilgili çok sayıda rivâyetin olması onun cömertlik yönünün çok güçlü olduğunu ispat ettiği sonucuna varılmıştır. Çocuklarına yönelik yapmış olduğu nasihatlerin önemli ahlâkî prensipler içerdiği görülmüştür.

Hz. Peygamber'i (s.a.s.) gördüğünden dolayı sahabî kabul edilen Saîd, çok az sayıda hadîs naklettiği tespit edilmiştir. Nakletmiş olduğu hadîslerin çoğunlukla çocukları tarafından nakledilmiştir. Az hadîs rivâyet etmesinde Hz. Peygamber vefat ettiğinde henüz dokuz yaşında 
Yerkazan, Kur'ân İstinsah Heyetinde Bulunan Saîd b. el-Âs kimdir?

olması, ömrünün büyük bir kısmı ordu komutanlığı ve valiliklerle geçmiş olmasından kaynaklanmış olabilir.

İslâm tarihinde önemli görevler üstlenmiş olan Saîd b. el-Âs gibi şahısların farklı boyutlarda ele alınıp incelenmesi ile bazı tarihî meselelerin çok daha iyi bir şekilde anlaşılabileceği görülmüştür.

\section{Kaynakça}

Abdurrezzak b. Hemmâm, Ebû Bekr es-San'ânî. el-Musannef. thk. Habibu'r-Rahman el-A'zamî. 11 Cilt. Beyrut: el-Mektebetü'l-İslamiyye, 1983.

Adıgüzel, Adnan. “Hz. Osman Döneminde (24-35/644-656) Fetihler”. Şarkiyat 11/3 (31 Aralık 2019), 1173-1199. https://doi.org/10.26791/sarkiat.604944

Ağbal, Davut. Tertîbu'l-Kur'ân. Ankara: Sonçağ Akademi.

Ahmed b. Hanbel. el-Müsned. thk. Şuayb Arnâût. 50 Cilt. Beyrut: Müessesetü’r-Risâle, 1999.

Apak, Adem. “Hz. Osman Dönemi Fetihleri”. Uludağ Üniversitesi İlahiyat Fakültesi Dergisi 9/1 (01 Ocak 2000). https://dergipark.org.tr/tr/pub/uluifd/163158

Beyhakî, Ebû Bekir Ahmed b. el-Hüseyin. Delâilu'n-nübüvve. 7 Cilt. Beyrut: Dâru'l-Kütübi'l-İlmiyye, 1988.

Beyhakî, Ebû Bekir Ahmed b. el-Hüseyin. Ma'rifetü’s-sünen ve'l-âsâr. thk. Abdulmu'tî Emîn Kal'acî. 15 Cilt. Beyrut: Dâru Kuteybe, 1991.

Beyhakî, Ebû Bekir Ahmed b. el-Hüseyin. es-Sünenü'l-kübra. thk. Muhammed Abdulkadir 'Atâ. 11 Cilt. Beyrut: Dâru'l-Kütübi'l-İlmiyye, 2003.

Beyhakî, Ebû Bekir Ahmed b. el-Hüseyin. Şu'abu'l-imân. thk. Abdulali Abdulhamîd Hâmid. 14 Cilt. Beyrut: Mektebetü'r-Rüşd, 2003.

Buhârî, Ebû Abdillâh Muhammed b. İsmâîl b. İbrâhîm el-Cu'fî. el-Edebü'l-Müfred. thk. Muhammed Fuâd Abdulbâkî. Beyrut: Dâru'l-Beşâiri'l-İslâmiyye, 1989.

Buhârî, Ebû Abdillâh Muhammed b. İsmail. el-Câmi'u's-sahîh. thk. Muhammed Züheyr b. Nasr. 8 Cilt. b.y.: Dâru Tavki'n-Necât, 1422/2001. 
Ebû Dâvûd, Süleymân b. el-Eş‘as b. İshâk es-Sicistânî el-Ezdî. el-Merâsîl. thk. Şuayb Arnâût. Beyrut: Müessesetü'r-Risale, 1408.

Ebû Dâvûd, Süleymân b. el-Eş‘as b. İshâk es-Sicistânî el-Ezdî. Sünenü Ebî Dâvûd. thk. Şuayb Arnâût, Muhammed Kâmil Karabellî. 7 Cilt. Beyrut: Dâru'r-Risâleti'l-'Âlemiyye, 2009.

Ebû Şâme, Ebü'l-Ḳâsım 'Abdurrahman b. İsmail el-Makdisî. el-Murşidu'l-vecîz 'ilâ 'ulûmin tete'allku bi'l-kitâbi'l-'azîz. thk. Tayyar Altıkulaç. Beyrut: Dâru Sadır, 1975.

Ebû Ubeyd, Kâsım b. Sellâm el-Herevî. Feḍ̂âilu'l-Kur'ân. thk. Mervân el-Ațiyye, Muhsin Hirâbe, Vefâ Takịuddîn. Beyrut - Dımaşk: Dâru İbn Kesîr, 1995.

Ezrakī, Ebü'l-Velîd Muhammed b. Abdillâh b. Ahmed b. Muhammed. Ahbâru Mekke. thk. Rüşdî Sâlih Melhas. 2 Cilt. Beyrut: Dâru'l-Endülüs, 1979.

Fâkihî, Ebû Abdillâh Muhammed b. İshâk b. Abbâs el-Fâkihî. Ahbâru Mekke. 6 Cilt. Beyrut: Dâru Hader, 1414.

Hâkim en-Nîsâbûrî, Ebû Abdillâh Muhammed b. Abdillâh b. Muhammed el-Müstedrek. thk. Yûsuf Abdurrahman el-Ma'raşlî. 4 Cilt. Beyrut: Dâru'l-Ma'rife, ty.

Harâitî, Ebû Bekr Muhammed b. Ca'fer b. Muhammed es-Sâmerrî. Mekârimü'l-ahlâk ve me'âlihhâ. thk. Eymen Abdulcâbir el-Buheyrî. Kahire: Dâru'l-Âfâk, 1999.

Harâitî, Ebû Bekr Muhammed b. Ca'fer b. Muhammed es-Sâmerrî. I'ttilâlü'l-ḳulûb. thk. Hamdî edDemirdâş. Riyad: Mektebetü Nezâr Mustafa el-Bâz, 2000.

İbn Abdilberr, Ebû Ömer Cemâlüddîn Yûsuf b. Abdillâh b. Muhammed en-Nemerî. el-İstî́âb fí ma'rifeti'l-așhâhb. thk. Ali Muhammed el-Becâvî. 4 Cilt. Beyrut: Dâru'l-Cîl, 1992.

İbn Ebî Âsım, Ebû Bekr Ahmed b. Amr b. ed-Dahhâk eş-Şeybânî. el-Âhâd ve'l-mesânî. 6 Cilt. Riyad: Dâru'r-Râye, 1991.

İbn Ebî Dâvûd Ebû Bekr Abdullah b. Ebî Dâvûd Süleymân b. Eş'as es-Sicistânî. Kitâbu'l-mesâhif. thk. Muhammed b. 'Abduh. Kâhire: el-Fāāūku'l-Ḥadīse, 2. Basım, 2011.

İbn Ebi'd-Dünyâ, Ebû Bekr Abdullah b. Muhammed el-Bağdâdî. Mekârimü'l-ahlâk. thk. Mecdî esSeyyîd İbrâhîm. Kahire: Mektebetü'l-Kur'ân, ty.

İbn Ebi'd-Dünyâ, Ebû Bekr Abdullah b. Muhammed b. Ubeyd el-Kureşî el-Bağdâdî. el-Hilm. thk. Muhammed Abdülkadir Ahmed Atâ. Beyrut: Müessesetü'l-Kütübi's-Sekâfiyye, 1413. 
Yerkazan, Kur'ân İstinsah Heyetinde Bulunan Saîd b. el-Âs kimdir?

İbn Ebi'd-Dünyâ, Ebû Bekr Abdullah b. Muhammed b. Ubeyd el-Kureşî el-Bağdâdî. el-i̇hvân. thk. Mustafa Abdulkadir Atâ. Beyrut: Dâru'l-Kütübi'l-i̇lmiyye, 1988.

İbn Ebi'd-Dünyâ, Ebû Bekr Abdullah b. Muhammed b. Ubeyd el-Kureşî el-Bağdâdî. el-İşrâf fî menâzili'l-eşrâf. thk. Necm Abdurrahman Halef. Riyad: Mektebetü'r-Rüşd, 1990.

İbn Ebi'd-Dünyâ, Ebû Bekr Abdullah b. Muhammed b. Ubeyd el-Kureşî el-Bağdâdî. es-Samt. thk. EbûIshâk el-Huveynî. Beyrut: Dâru'l-Kitâbi'l-Arabî, 1410.

İbn Ebi'd-Dünyâ, Ebû Bekr Abdullah b. Muhammed b. Ubeyd el-Kureşî el-Bağdâdî. Kadâu'l-havâici. thk. Muhammed Abdülkadir Ahmed Atâ. Beyrut: Müessesetü'l-Kütübi's-Sekâfiyye, 1993.

İbn Ebî Şeybe, Ebû Bekr Abdullah b. Muhammed. el-Musannef. thk. Muhammed Avvâme. 26 Cilt. Beyrut: Dâru'l-Kıble, 2006.

İbn Hacer, Ebü'l-Fazl Şihâbüddîn Ahmed b. Alî b. Muhammed el-Askalânî. el-ișâbe fì temyîzi's-sahâbe. thk. Âdil Ahmed Abdülmevcûd, Ali Muhammed Muavvid. 8 Cilt. Beyrut: Dâru'l-Kütübi'lİlmiyye, 1994.

İbn Ḥazm, Ebû Muhammed 'Alî b. Ahmed el-Endelusî. el-Muhallâ bi'l-Âsâr. thk. Abdulğaffâr Süleyman el-Bundârî. 12 Cilt. Beyrut: Dâru'l-Fikr, 2002.

İbn Kesîr, Ebü'l-Fidâ’ İmâdüddîn İsmâîl b. Şihâbiddîn Ömer b. Kesîr b. Dav' b. Kesîr el-Kaysî elKureşî el-Busrâvî ed-Dımaşkī. el-Bidâye ve’n-nihâye. 15 Cilt. Dımaşk: Dâru'l-Fikr, 1986.

İbn Manzûr, Ebü'l-Fazl Cemâlüddîn Muhammed b. Mükerrem b. Alî b. Ahmed el-Ensârî er-Rüveyfiî. Muhtașaru Târîhi Dımaşk. 29 Cilt. Dımaşk: Dâru'l-Fikr, 1984.

İbnü'l-Münzir, Ebû Bekr Muhammed b. İbrâhîm en-Nîsâbûrî. el-Evsat fís-sünen ve'l-icmấ ve'l-ihtilâf. thk. Ebû Hammâd Sağîr b. Ahmed b. Muhammed. Riyad: Dâru Taybe, 1985.

İbn Sa'd, Ebû Abdillâh Muhammed b. Sa'd b. Menî‘ el-Kâtib el-Hâşimî el-Basrî el-Bağdâdî. etTabakātü'l-Kübrâ. thk. Muhammed Abdülkadir Atâ. 8 Cilt. Beyrut: Dâru'l-Kütübi'l-İlmiyye, 1990.

İbn Şebbe, Ebû Zeyd Ömer b. Şebbe en-Nümeyrî el-Basrî. Târîhu'l-Medîne. thk. Fehim Muhammed Şeltût. 4 Cilt. Cidde: y.y., 1979.

İbn Vehb, Ebû Muhammed 'Abdullâh b. Vehb el-Misrî el-Kureşî. Tefsîru'l-Kur'ân. thk. Miklos Muranyi. 3 Cilt. Beyrut: Dâru'l-Ğarbi'l-İslâmî, 2003. 
İmâm Malik, Ebû Abdillâh Mâlik b. Enes el-Asbahî. Muvatta. thk. Muhammed Mustafa el-A'zami. 8 Cilt. Abu Dabi: Devletü'l-Emarati'l-Arabiyyeti'l-Müttahide, 2004.

Ma'mer b. Râşid el-Basrî es-San'ânî. el-Câmi'. thk. Habiburrahman el-A'zâmî. 11 Cilt. Beyrut: Mektebetü'l-İslamiye, 1403.

Maşal1, Mehmet Emin. "Mushaf”. Türkiye Diyanet Vakfi İslam Ansiklopedisi. 31/242-248. İstanbul: TDV Yayınları, 2006.

Mizzî, Ebü'l-Haccâc Cemâlüddîn Yûsuf b. Abdirrahmân b. Yûsuf. Tehzî̉ü̈l-Kemâl fî esmầi'r-ricâl. thk. Beşşâr Avvâd Ma'ruf. 35 Cilt. Beyrut: Müessesetü'r-Risâle, 1980.

Müslim, Ebü’l-Hüseyn Müslim b. Haccâc. Sahihu Müslim. Riyad: Dâru Tîbe, 1. Basım, 2006.

Taberânî, Ebü'l-Kāsım Müsnidü'd-dünyâ Süleymân b. Ahmed b. Eyyûb. el-Mu'cemu'l-kebîr. thk. Hamdi Abdulmecîd es-Selefî. 25 Cilt. Kahire: Mektebetü İbn Teymiyye, 1983.

Tayâlisî, Ebû Dâvûd Süleymân b. Dâvûd b. el-Cârûd. el-Müsned. thk. Muhammed b. Abdilmuhsin etTürkî. 4 Cilt. Mısır: Dâru Hacer, 1994.

Tirmizî, Ebû Îsâ Muhammed b. Îsâ. Sünenü't-Tirmizî. thk. Beşşâr Avvâd Ma'ruf. 6 Cilt. Beyrut: Dâru'lGarbi'l-İslâmî, 1998.

Yıldız, Hakkı Dursun. Doğuştan Günümüze Büyük İslam Tarihi. 1-14+Ek Cilt. İstanbul: Çağ Yayınları, 1992.

Zehebî, Ebû Abdillâh Şemseddin Muhammed b. Ahmed b. Osman. Siyeru a'lami'n-nübela 2. thk. Şuayb Arnaûd. 25 Cilt. Beyrut: Müessestü'r-Risale, 1982. 
Yerkazan, Kur'ân İstinsah Heyetinde Bulunan Saîd b. el-Âs kimdir?

Who is Saîd b. al-As in the commission for the reproduction of the Holy Quran?

Assoc. Prof. Hasan YERKAZAN

\section{Extended Summary}

Saîd b. al-As was born in Mecca in the year of Hijrah. His father al-As, was on the side of the polytheists in the Battle of Badr, and Ali was killed by him. Saîd orphaned at a young age, grew up under the auspices of Uthman, who was a member of the same family as him.

Saîd b. al-As participated in the Armenian and Azerbaijani expeditions in the time of Omar and Uthman and achieved great success here. During these expeditions, he witnessed that the Qur'an was recited with different recitations among Iraqi and Syrian soldiers, and he was in the commission of copying of the Qur'an, which was established to put an end to this confusion. It is thought that the fact that Saîd b. al-As witnessed different Qur'anic recitations as an army commander during the conquests of Azerbaijan and Armenia was the most effective in his taking part in this commission. However, the main reason for his being in this commission is his knowledge of the Qur'an, having a brilliant comprehension of the Arabic language, and his eloquent and well-spoken language skills. Additionally, his similarity to the Prophet in terms of dialect was also effective in his appointment to the commission of copying.

Saîd b. al-As, who was brought up under Uthman's upbringing, proved himself at a very young age with his knowledge and experience. He was appointed as a governor of Kufa on 30/650. He found himself in turmoil and chaos when he came to Kufa. Although he was a young and inexperienced person when he came to Kufa as the governor, he tried to make himself accepted by the people in a short time. On the days when the governor was appointed to Kufa, the Azerbaijanis broke the agreement they made with the Muslims. Saîd went against them and conquered Tabaristan and Curcan. In Kufa, where chaos was never lacking, the people of Kufa did not give comfort to Saîd b. al-As. They even came to Madina and asked Uthman to dismiss Saîd b. al-As. Uthman, who wanted to end the chaos, accepted the requests of the people of Kufa, but it did not end. Because the decision Uthman gave about Kufa brought the weakness of authority to light. The rebels encouraged from this, made the caliphate Uthman controversial, and as a result, Uthman was martyred.

Saîd b. al-As was among the group that set out for Mecca to avenge Uthman after his martyrdom. However, he realized that there was a danger and conflict that would arise among the Muslims, and he did not find it right to be among this community and went to Taif and did not participate in the battles of Jamel and Siffin. Saîd did not participate in the political struggle of Muawiya and remained impartial. After Ali was martyred, he went to Muawiyah. Later, he was 
appointed as a governor of Madina by Muawiya. Saîd b. al-As tried to get along with people in the places where he worked and became famous for his generosity. He did not turn down those who demanded something from him.

Because Saîd b. al-As is a Companion, his words are considered as mawkûf hadith. In the sources, there are advices that begin with an address sentence directly their children like "O my son!". He took care of the decency and upbringing of his children. In this article, it is possible to list the results about Saîd b. al-As as follows:

The father of Saîd b. al-As was killed by Ali while he was on the side of the polytheists in the Battle of Badr. For this reason, it could not be determined that he had any resentment or hostility towards Ali. On the contrary, he sent special gifts to Ali during his governorship in Kufa. He was the governor of Madina, although Muawiya was in power, he did not show any disrespect towards the Ahl al-Bayt. He also wanted to marry Umm Kulthum, Ali's daughter.

He had good relations with Hasan and Husayn during his duty in Madina. He tried not to upset these people. Because Husayn did not give consent him to marry Umm Kulthum, he gave up the marriage although he gave the mahr. It is possible to say that this attitude is due to the respect he showed to the Ahl al-Bayt. The main reason why Husayn did not approve this marriage could not be determined exactly. Being the governor of Muawiya, being neutral during the wars of Jamel and Siffin, being a member of the Umayyad family, etc. such matters are possible. However, it is impossible to say for sure.

He commanded the armies including great Companions and sought the opinions of experienced people in religious, scientific, and political matters. This behavior shows that he attaches importance to consultation.

He was included in the commission established to reproduce the copies of the Qur'an due to his virtues such as his knowledge of the Qur'an, brilliant comprehension of the Arabic language, and his eloquent and well-spoken language skills, and the resemblance of his dialect to the Prophet's. His main task in the commission was correcting the spelling of words. Except a few examples, it has not been determined exactly in which surahs, verses and words there was disagreement and how long this commission completed its responsibility. It has been concluded that the Qur'an was copied between the years 26-30 Hijri, taking into account only the wars and the dates during the term of office of the governors.

It was observed that he adopted a strict management style during his time in Kufa. Saîd, who had difficulty in maintaining order in this city where chaos and turmoil was not missing, was dismissed. His dismissal from the governorship also shook the authority of Uthman and paved the way for his caliphate to come to an end. It is understood that by remaining impartial in the wars of Jamal and Siffin, he did not tolerate the conflict of Muslims with each other. 
He tried to take Omar as his guide rather than Uthman as a management style. It has been determined that he followed Omar while he was alive and tried to get to know him better, even indirectly, by wanting to marry his widowed wives after his death.

He was famous for his generosity. It was seen that he gave a large amount of money to the needy, especially while he was working in Madina. Although some of the dirhams and dinars he gave may seem like an exaggeration, it has been concluded that the fact that there are lots of narrations on the subject proves that his aspect of generosity was very strong.

It has been determined that Saîd, who was accepted as a Companion because he saw the Prophet himself (pbup), transmitted very few hadiths. The hadiths he narrated were mostly transmitted by his children. The reason why he narrated few hadiths may be that he was only nine years old when the Prophet passed away, and that he spent most of his life in command of the army and governorships.

It has been seen that some historical issues can be understood in a much better way by examining individuals such as Saîd b. al-As, who has undertaken important tasks in the history of Islam with different dimensions.

Keywords: Islamic History, Quran History, Said b. al-As, Kufa, Medina. 
Yerkazan, Who is Saîd b. al-As in the commission for the reproduction of the Holy Quran? 